\title{
Derivation of greenhouse gas emission factors for peatlands managed for extraction in the Republic of Ireland and the United Kingdom
}

\author{
D. Wilson ${ }^{1}$, S. D. Dixon ${ }^{2}$, R. R. E. Artz ${ }^{3}$, T. E. L. Smith $^{4}$, C. D. Evans ${ }^{5}$, H. J. F. Owen ${ }^{4}$, E. Archer ${ }^{2}$, and \\ F. Renou-Wilson 6 \\ ${ }^{1}$ Earthy Matters Environmental Consultants, Glenvar, Co. Donegal, Ireland \\ ${ }^{2}$ Department of Earth Sciences, University of Durham, Durham, UK \\ ${ }^{3}$ The James Hutton Institute, Aberdeen, Scotland, UK \\ ${ }^{4}$ King's College London, Department of Geography, Strand, London, UK \\ ${ }^{5}$ Centre for Ecology and Hydrology, Bangor, Wales, UK \\ ${ }^{6}$ School of Biology \& Environmental Science, University College Dublin, Dublin, Ireland
}

Correspondence to: D. Wilson (david.wilson@earthymatters.ie)

Received: 25 March 2015 - Published in Biogeosciences Discuss.: 20 May 2015

Revised: 3 August 2015 - Accepted: 30 August 2015 - Published: 16 September 2015

\begin{abstract}
Drained peatlands are significant hotspots of carbon dioxide $\left(\mathrm{CO}_{2}\right)$ emissions and may also be more vulnerable to fire with its associated gaseous emissions. Under the United Nations Framework Convention on Climate Change (UNFCCC) and the Kyoto Protocol, greenhouse gas (GHG) emissions from peatlands managed for extraction are reported on an annual basis. However, the Tier 1 (default) emission factors (EFs) provided in the IPCC 2013 Wetlands Supplement for this land use category may not be representative in all cases and countries are encouraged to move to highertier reporting levels with reduced uncertainty levels based on country- or regional-specific data. In this study, we quantified (1) $\mathrm{CO}_{2}-\mathrm{C}$ emissions from nine peat extraction sites in the Republic of Ireland and the United Kingdom, which were initially disaggregated by land use type (industrial versus domestic peat extraction), and (2) a range of GHGs that are released to the atmosphere with the burning of peat. Drainagerelated methane $\left(\mathrm{CH}_{4}\right)$ and nitrous oxide $\left(\mathrm{N}_{2} \mathrm{O}\right)$ emissions as well as $\mathrm{CO}_{2}-\mathrm{C}$ emissions associated with the off-site decomposition of horticultural peat were not included here. Our results show that net $\mathrm{CO}_{2}-\mathrm{C}$ emissions were strongly controlled by soil temperature at the industrial sites (bare peat) and by soil temperature and leaf area index at the vegetated domestic sites. Our derived EFs of $1.70( \pm 0.47)$ and 1.64 $( \pm 0.44) \mathrm{tCO}_{2}-\mathrm{C} \mathrm{ha}^{-1} \mathrm{yr}^{-1}$ for the industrial and domestic
\end{abstract}

sites respectively are considerably lower than the Tier $1 \mathrm{EF}$ $\left(2.8 \pm 1.7 \mathrm{tCO}_{2}-\mathrm{Cha}^{-1} \mathrm{yr}^{-1}\right)$ provided in the Wetlands Supplement. We propose that the difference between our derived values and the Wetlands Supplement value is due to differences in peat quality and, consequently, decomposition rates. Emissions from burning of the peat $\left(\mathrm{g} \mathrm{kg}^{-1}\right.$ dry fuel burned) were estimated to be approximately $1346 \mathrm{CO}_{2}, 8.35$ methane $\left(\mathrm{CH}_{4}\right), 218$ carbon monoxide $(\mathrm{CO}), 1.53$ ethane $\left(\mathrm{C}_{2} \mathrm{H}_{6}\right), 1.74$ ethylene $\left(\mathrm{C}_{2} \mathrm{H}_{4}\right), 0.60$ methanol $\left(\mathrm{CH}_{3} \mathrm{OH}\right), 2.21$ hydrogen cyanide $(\mathrm{HCN})$ and 0.73 ammonia $\left(\mathrm{NH}_{3}\right)$, and this emphasises the importance of understanding the full suite of trace gas emissions from biomass burning. Our results highlight the importance of generating reliable Tier 2 values for different regions and land use categories. Furthermore, given that the IPCC Tier 1 EF was only based on 20 sites (all from Canada and Fennoscandia), we suggest that data from another 9 sites significantly expand the global data set, as well as adding a new region.

\section{Introduction}

Greenhouse gas (GHG) emissions to the atmosphere have increased significantly since pre-industrial times as a direct result of human activities, such as fossil fuel burning, cement 
production and land use changes (IPCC, 2013). The Intergovernmental Panel on Climate Change (IPCC) have estimated in their Fifth Assessment Report (AR5) that around one third of all anthropogenic emissions of carbon dioxide $\left(\mathrm{CO}_{2}\right)$ for the period 1750-2011, were caused by land use changes (IPCC, 2013). From 2000 to 2009, the Agriculture, Forestry and Other Land Use (AFOLU) sector accounted for $24 \%$ of all global GHG emissions (around $10 \mathrm{GtCO}_{2}$ eq $\mathrm{yr}^{-1}$ ), with emissions from peatland drainage and burning alone estimated at around $0.9 \mathrm{GtCO}_{2}-\mathrm{eq} \mathrm{yr}^{-1}$.

Natural (i.e. undrained) peatlands function as long-term carbon $(\mathrm{C})$ stores as the sequestration of $\mathrm{CO}_{2}$ over time is greater than the amount of $\mathrm{C}$ that is emitted from the peatland as methane $\left(\mathrm{CH}_{4}\right)$ and leached in waterborne exports (Roulet et al., 2007; Nilsson et al., 2008; Koehler et al., 2011; Gažovič et al., 2013). Key to this role is the position of the water table, which largely dictates the rate of decomposition within the peatland. When the water table is positioned close to the peat surface, the breakdown and degradation of organic matter typically proceeds very slowly in the absence of oxygen. As a consequence, there is an accumulation of peat (and C within; Dise, 2009).

In the Republic of Ireland (ROI) and the United Kingdom (UK), peat has been extracted for energy use for many centuries (Chapman et al., 2003; Renou et al., 2006). Traditionally, this involved the manual removal of the peat, i.e. hand cutting; however, this has been largely superseded by highly mechanised methods to extract the peat for both energy and horticulture requirements. In the ROI, over 4 million tonnes of peat per annum are industrially extracted from approximately 50000 ha to provide ca. $5.5 \%$ of primary energy requirements (Howley et al., 2012) and for use in horticulture. A further 0.4 million tonnes per year is likely burned for domestic heating (Duffy et al., 2014) and may impact as much as 600000 ha of peatlands (Wilson et al., 2013b). Although peat extraction areas in the UK have generally declined over the last few decades, approximately 0.8 million tonnes of peat is still extracted each year in England and Scotland (Webb et al., 2014), although it is UK Government policy to phase out peat extraction in England by 2030 (Department of Environment Food and Rural Affairs, 2011). Peat extraction areas in Wales are small (482 ha) and have remained unchanged in the 1991-2010 period (Webb et al., 2014). In Northern Ireland, the area of peatland utilised for fuel (mechanical and hand cutting) has declined considerably in the 1990-2008 period, although a slight increase in the areas used for horticulture have been recorded (Tomlinson, 2010).

In industrial peatlands, the extraction of peat is facilitated by the installation of drainage ditches at regular (typically $15-30 \mathrm{~m}$ ) intervals across the peatland. For peat used for horticultural purposes, the more fibrous upper layers (e.g. Sphagnum peat) are extracted and utilised. If the peat is to be used for energy production the more highly decomposed peat is milled, dried in the production fields and removed for immediate use or stockpiled for later requirements. Peat extraction ceases for energy production when either the subpeat mineral soil is reached, large quantities of fossilised timber are encountered or drainage is no longer practical (Farrell and Doyle, 2003). For peatlands used for the provision of domestic heating, the peat is either removed by a digger from the margins of peatlands, placed in a tractor-mounted hopper and extruded onto the surface of the peatland, or the peat is extruded onto the surface of the peatland from openings made in the peat by a chain cutter. Over a period of weeks the peat is dried in situ and removed from the site. The effect of peat extraction on the hydrological functioning is marked by a large fall in the water level either throughout the peatland (industrial) or at the margins of the peatland (domestic). In the latter, significant water level drawdown is also experienced further inward towards the centre of the peatland (Schouten, 2002).

The impact of drainage on $\mathrm{C}$ cycling in peatlands has been widely documented. In general, a lowering of the water table leads to increased $\mathrm{CO}_{2}$ emissions (Silvola et al., 1996; Salm et al., 2012; Haddaway et al., 2014) as the aerobic layer is deepened and mineralisation rates are accentuated. Concurrently, $\mathrm{CH}_{4}$ emissions (with the exception of emissions from ditches) may decrease or cease (Salm et al., 2012; Turetsky et al., 2014), waterborne $C$ exports may increase (Strack et al., 2008; Evans et al., 2015) and there may be a heightened risk of $C$ loss through fire (Turetsky et al., 2015). In the case of peat extraction, $\mathrm{C}$ cycling may be further altered by the removal of vegetation (Waddington and Price, 2000), and losses of windblown particulate organic carbon (POC) may be exacerbated from the bare peat surfaces (Lindsay, 2010).

Under the United Nations Framework Convention on Climate Change (UNFCCC) and the Kyoto Protocol, "Annex 1 " countries (i.e. countries that have committed to targets that limit or reduce emissions) are obligated to prepare annual National Inventory Reports (NIR) and up-to-date annual inventories, detailing GHG emissions and removals from six different sectors. Emissions associated with off-site peat combustion are reported under the Energy sector and are not considered further here. The recent IPCC Wetlands Supplement (IPCC, 2014) to the 2006 Good Practice Guidance (GPG; IPCC, 2006) derived new Tier 1 emission factors (EFs) for drained organic soils that differentiated between on-site emissions (e.g. $\mathrm{CO}_{2}-\mathrm{C}_{\text {on-site }}$, fire) and off-site losses (e.g. leaching of waterborne $\mathrm{C}$ ). In the case of peatlands managed for extraction in the temperate climate zone, the $\mathrm{CO}_{2}-$ $\mathrm{C}_{\text {on-site }}$ values have increased from 0.2 (nutrient-poor, bogs) and 1.1 (nutrient-rich, fens) $\mathrm{tCO}_{2}-\mathrm{C} \mathrm{ha}^{-1} \mathrm{yr}^{-1}$ in the 2006 GPG to a single higher EF of $2.8 \mathrm{tCO}_{2}-\mathrm{Cha}^{-1} \mathrm{yr}^{-1}$ (covering the entire boreal and temperate regions) in the Wetlands Supplement. On-site burning directly consumes aboveground $\mathrm{C}$ stocks (prescribed and wildfire burning) and the underlying peat $\mathrm{C}$ store (wildfire burning) and rapidly releases both gases (e.g. $\mathrm{CO}_{2}, \mathrm{CH}_{4}$ ) and particulates (e.g. black carbon) to the atmosphere. In the Wetlands Supplement, an 
EF for GHG emissions from prescribed fire on drained peatlands is not provided due to a paucity of published data at present. However, emissions from wildfires are addressed and EFs of 362,9 and $207 \mathrm{~g} \mathrm{~kg}^{-1}$ dry fuel burned are provided for $\mathrm{CO}_{2}-\mathrm{C}, \mathrm{CH}_{4}$ and $\mathrm{CO}$ respectively with a proviso that they were derived from a very small data set.

Given the relatively large areas under peat extraction in both the ROI and the UK, a move from Tier 1 to higher reporting levels is desirable, particularly as (a) a wide range in uncertainty is associated with the IPCC Tier 1 values (1.1$4.2 \mathrm{t} \mathrm{CO}_{2}-\mathrm{C} \mathrm{ha}^{-1} \mathrm{yr}^{-1}$ ), which reflects the disparity in emissions from drained peatlands from different climate zones and nutrient composition, (b) the most recently published annual $\mathrm{CO}_{2}$ flux estimates (not included in the derivation of IPCC Tier 1 values) also display a very wide amplitude (cf. Järveoja et al., 2012; Mander et al., 2012; Salm et al., 2012; Strack et al., 2014), (c) no data from ROI or UK peatlands were included in the IPCC derivation, which might mean that the Tier 1 value may not be appropriate for these countries, and (d) no distinction is made between industrial or domestic extraction sites, despite large differences in their drainage, vegetation cover and management characteristics. In addition, previous studies of peatland fire EFs have focused on the boreal peatlands of Alaska (Yokelson et al., 1997) and Canada (Stockwell et al., 2014) and the temperate peatlands of Minnesota (Yokelson et al., 1997) and North Carolina (Stockwell et al., 2014). These studies found that the smouldering combustion of peats associated with low combustion efficiency leads to relatively lower $\mathrm{CO}_{2}$ emissions (compared with other ecosystems) and much higher carbon monoxide (CO), $\mathrm{CH}_{4}$, and other non- $\mathrm{CH}_{4}$ hydrocarbon emissions. Therefore, it is important to quantify emissions of these gases as they include strong GHGs (e.g. $\mathrm{CH}_{4}$ ) and reactive gases responsible for tropospheric ozone formation and poor air quality (e.g. $\mathrm{CO}$, ammonia $\left(\mathrm{NH}_{3}\right)$, hydrogen cyanide (HCN)).

The objectives of the study are (1) to provide estimates of the annual $\mathrm{CO}_{2}-\mathrm{C}$ exchange (i.e. $\mathrm{CO}_{2}-\mathrm{C}_{\text {on-site }}$ ) for nine peat extraction sites in the ROI and the UK, (2) to derive regional-specific $\mathrm{CO}_{2}-\mathrm{C}$ EFs for drained peat extraction areas that would permit the ROI and the UK to progress to the Tier 2 reporting level, (3) analyse the factors that influence $\mathrm{CO}_{2}-\mathrm{C}$ dynamics in this region (i.e. land use, climate, etc.), and (4) to report GHG emissions associated with the burning of Irish Sphagnum moss peat in the first laboratory study to investigate fire emissions from European temperate peats.

\section{Materials and methods}

\subsection{Study sites}

The study sites were located at nine peat extraction areas in the ROI and the UK with a history of either industrial peat (IP) or domestic peat (DP) extraction (Table 1). Boora (IP1),
Blackwater (IP2), Bellacorick (IP3), Turraun (IP4), Middlemuir Moss (IP5) and Little Woolden Hall Moss (IP6) are industrial cutaway peatlands where significant areas of bare peat (i.e. unvegetated microsites) have remained following the cessation of milled peat extraction. At IP6, milled peat is currently extracted from areas close $(<150 \mathrm{~m})$ to the study site. The IP sites are former raised bogs with the exception of IP3, which is a former Atlantic blanket bog. At all sites, the drainage ditches have remained functional. Here we define "drained" as a mean annual water table position deeper than $-20 \mathrm{~cm}$ (Couwenberg and Fritze, 2012; Strack et al., 2014). Physico-chemical characteristics of all the sites are detailed in Table 1.

At Clara (DP1), Glenlahan (DP2) and Moyarwood (DP3) the peat has been extracted from the margins of the sites for use in domestic heating. In the case of Clara, peat extraction was an ongoing activity at the time of our study despite the designation of the site as a Special Area of Conservation (SAC). DP1 and DP3 are raised bogs and DP2 is a mountain blanket bog. The vegetation component at all the sites is species poor and is composed mainly of ling heather (Calluna vulgaris), cross-leaved heather (Erica tetralix) and lichens (Cladonia spp.) A continuous water table level was not observed at DP2, as the relatively shallow peat deposit ( $\sim 40 \mathrm{~cm}$ ) over bedrock at that site was prone to drying out at various times throughout the study.

\subsection{Climatic conditions}

All the sites are located within the temperate zone as defined by IPCC (2006) and are characterised by an oceanic climate with prevailing south-west winds, mild mean annual air temperatures $\left(8\right.$ to $\left.10.3^{\circ} \mathrm{C}\right)$ and moderate to high annual rainfall (804 to $1245 \mathrm{~mm}$; Table 1 ).

\subsection{Environmental monitoring}

At each site, three to nine aluminium square collars $(60 \times 60 \mathrm{~cm})$ were inserted to a depth of $30 \mathrm{~cm}$ into the peat. At IP6, smaller circular plastic collars were used $(15 \mathrm{~cm}$ diameter) to facilitate the use of the CPY-4 chamber (PP Systems, UK) at that site. Soil loggers ( $\mu$ logger, Zeta-tec, UK; HOBO external data loggers, Onset Computer Corporation, MA, USA; Comark N2012 Diligence loggers, Norwich, UK) were established at all the IP sites and recorded soil temperatures $\left({ }^{\circ} \mathrm{C}\right)$ at hourly intervals. Weather stations were installed at all the DP sites and recorded photosynthetic photon flux density (PPFD; $\mu \mathrm{mol} \mathrm{m} \mathrm{m}^{-2} \mathrm{~s}^{-1}$ ) and soil temperatures (5 and $10 \mathrm{~cm}$ depths) at $10 \mathrm{~min}$ intervals. At DP3, soil volumetric moisture content (VMC, \%) was also recorded (at $10 \mathrm{~min}$ intervals) by the weather station at that site. At sites IP5 and IP6, soil temperature was only measured manually during $\mathrm{CO}_{2}$ flux measurements. In order to estimate soil temperature at times where data was lacking at these two sites, a regression-based approach between manually recorded $T_{5} \mathrm{~cm}$ 
Table 1. Site characteristics. Mean annual air temperature $\left({ }^{\circ} \mathrm{C}\right)$ and mean annual rainfall (mm yr $\left.{ }^{-1}\right)$ are long-term values $(1981-2010$; Met Éireann, http://www.met.ie/, and Met Office UK, http://www.metoffice.gov.uk).

\begin{tabular}{|c|c|c|c|c|c|c|c|c|c|}
\hline Site name & Boora & Blackwater & Bellacorick & Turraun & $\begin{array}{r}\text { Middlemuir } \\
\text { Moss } \\
\text { IP5 }\end{array}$ & $\begin{array}{r}\text { Little } \\
\text { Woolden } \\
\text { IP6 }\end{array}$ & Clara & Glenlahan & Moyarwood \\
\hline $\begin{array}{l}\text { Time since last } \\
\text { extraction* }\end{array}$ & $>20$ years & $>25$ years & $>10$ years & $>30$ years & $>10$ years & ca. 1 & 0 & $>20$ years & $>20$ years \\
\hline Study period & $\begin{array}{l}1 / 9 / 2007- \\
30 / 8 / 2009\end{array}$ & $\begin{array}{l}1 / 5 / 2011- \\
30 / 4 / 2014\end{array}$ & $\begin{array}{r}1 / 1 / 2012- \\
31 / 12 / 2013\end{array}$ & $\begin{array}{r}1 / 1 / 2002- \\
31 / 12 / 2003\end{array}$ & $\begin{array}{l}1 / 11 / 2003- \\
31 / 10 / 2004\end{array}$ & $\begin{array}{r}1 / 1 / 2013- \\
31 / 12 / 2014\end{array}$ & $\begin{array}{l}1 / 4 / 2006- \\
31 / 3 / 2007\end{array}$ & $\begin{array}{l}1 / 4 / 2006- \\
31 / 3 / 2007\end{array}$ & $\begin{array}{l}1 / 4 / 2013- \\
31 / 3 / 2014\end{array}$ \\
\hline Latitude & 53.203 & 53.297 & 54.128 & 53.260 & 57.60 & 53.451 & 53.316 & 53.103 & 53.346 \\
\hline Longitude & -7.726 & -7.965 & -9.556 & -7.720 & -2.15 & -2.468 & -7.647 & -7.538 & -8.514 \\
\hline Subregion & Irish & Irish & North-west & Irish & North-east & Northern & Irish & Irish & Western \\
\hline $\begin{array}{l}\text { Mean annual air } \\
\text { temperature }\left({ }^{\circ} \mathrm{C}\right)\end{array}$ & $\begin{array}{r}\text { Midlands } \\
9.3\end{array}$ & $\begin{array}{r}\text { Midlands } \\
9.8\end{array}$ & $\begin{array}{r}\text { Ireland } \\
10.3\end{array}$ & $\begin{array}{r}\text { Midlands } \\
9.3\end{array}$ & $\begin{array}{r}\text { Scotland } \\
8.0\end{array}$ & $\begin{array}{r}\text { England } \\
10.2\end{array}$ & $\begin{array}{r}\text { Midlands } \\
9.3\end{array}$ & $\begin{array}{r}\text { Midlands } \\
9.3\end{array}$ & $\begin{array}{r}\text { Ireland } \\
10.0\end{array}$ \\
\hline $\begin{array}{l}\text { Mean annual } \\
\text { rainfall }\left(\mathrm{mm} \mathrm{yr}^{-1}\right)\end{array}$ & 970 & 907 & 1245 & 807 & 851 & 867 & 970 & 804 & 1193 \\
\hline Vegetation & & & & & & & Calluna $v$ & iris, Erica tetralix, & Cladonia sp. \\
\hline Peat type & Phragmites & Phragmites & Cyperaceous & Phragmites & $\begin{array}{l}\text { Sphagnum/ } \\
\text { cyperaceous }\end{array}$ & $\begin{array}{l}\text { Sphagnum/ } \\
\text { cyperaceous }\end{array}$ & Sphagnum & Ericaceous & Sphagnum \\
\hline Von Post scale & $\mathrm{H} 7$ & $\mathrm{H} 7$ & $\mathrm{H} 5$ to 6 & $\mathrm{H} 7$ & $\mathrm{H} 8$ & H6 to 7 & H6 & H6 & H6 \\
\hline Parent material & Limestone & Limestone & Shale & Limestone & $\begin{array}{r}\text { Granite drifts } \\
\text { and rocks }\end{array}$ & $\begin{array}{r}\text { Triassic } \\
\text { sandstone }\end{array}$ & Limestone & Old Red Sandstone & Limestone \\
\hline Peat depth (m) & 1.0 & 1.5 & 0.5 & $0.5-1.8$ & $0.7-3.1$ & $0.5-1.75$ & 4 & 0.4 & 4.4 \\
\hline $\mathrm{pH}$ & 4.3 & 4.9 & 3.8 & 6.3 & $3.6-4.1$ & 2.9 & 4.0 & 3.8 & 4.4 \\
\hline $\mathrm{C}(\%)$ & 50 & 52.4 & 56 & 52 & 52 & 49.1 & 49.8 & 29.1 & 51.5 \\
\hline $\mathrm{N}(\%)$ & 1.09 & 2.14 & 0.97 & 2.1 & 1.4 & 1.34 & 1.46 & 0.69 & 1.32 \\
\hline$C: N$ & 45.9 & 24.5 & 57.7 & 24.8 & 37 & 36.6 & 34.1 & 42.2 & 39 \\
\hline
\end{tabular}

* Time between cessation of peat extraction and the study period.

and air temperature recorded at $15 \mathrm{~min}$ intervals by a logger at the site was used to gap-fill the data $\left(r^{2}=88.7 \%\right)$. The water table level (WT) was manually measured from dipwells (internal diameter $2 \mathrm{~cm}$ ) inserted adjacent to each collar. Wooden boardwalks were established at each site (except at IP6).

\subsection{Leaf area index (LAI)}

At the IP sites, the vegetation had been removed prior to the commencement of peat extraction and virtually no natural recolonisation has taken place following the cessation of peat extraction. However, at the DP sites a vegetation component was present and in order to incorporate the seasonal dynamics of the plants into $\mathrm{CO}_{2}-\mathrm{C}$ exchange models, the leaf area index (LAI) was estimated for each of the collars. This involved accounting for the green photosynthetic area of all vascular plants (leaves and stems) within the collar at monthly intervals. In short, the number of leaves and stems were counted from five subplots $(8 \times 8 \mathrm{~cm})$ within each collar. The size (length, width) of the leaves was measured from sample plants outside the collars. The LAI was then calculated by multiplying the estimated number of leaves by an area estimate of the leaf. Moss and lichen percentage cover was estimated at the same time. Species-specific model curves were applied to describe the phenological dynamics of the vegetation of each collar, and the models (vascular plants and moss) were summed to produce a plot-specific LAI. For a detailed description of the method, see Wilson et al. (2007). At site DP1 only, the vegetation was removed by regular clipping from one third of the collars, in order to provide an estimate of the heterotrophic contribution $\left(R_{\mathrm{H}}\right)$ to ecosystem respiration $\left(R_{\mathrm{eco}}\right)$.

\subsection{On-site carbon dioxide flux estimation}

\subsubsection{Field measurements}

At sites IP1-5 and DP1-3, $R_{\text {eco }}$ was measured with a static polycarbonate chamber $(60 \times 60 \times 33 \mathrm{~cm})$ equipped with two internal fans to ensure mixing of the air within the chamber and a cooling system (submerged ice packs and water pumped to a radiator located within the chamber) to maintain the temperature within the chamber close to the ambient air temperature (for a more detailed description, see Alm et al., 2007b). At IP6, $R_{\text {eco }}$ was measured with a CPY4 (PP Systems, UK) clear acrylic chamber $(14.6 \mathrm{~cm}$ diameter, $14.5 \mathrm{~cm}$ height). The CPY-4 chamber was equipped with an internal fan, PPFD sensor and thermistor. Sampling was carried out at fortnightly or monthly (winter) intervals (two to four measurements per collar per measurement day). For each $R_{\text {eco }}$ flux measurement, the chamber was placed in a water-filled channel at the top of the collar or connected with a rubber gasket (IP5), covered with an opaque cover, and the $\mathrm{CO}_{2}$ concentration (ppmv) in the chamber headspace was measured at $15 \mathrm{~s}$ ( $5 \mathrm{~s}$ at IP6) intervals over a period of 
60-180 s using a portable $\mathrm{CO}_{2}$ analyser (EGM-4, PP Systems, UK). Concurrently, air temperature $\left({ }^{\circ} \mathrm{C}\right)$ within the chamber and soil temperatures at 5,10 and $20 \mathrm{~cm}$ depths were recorded at each collar (soil temperature probe, ELE International, UK). The WT position relative to the soil surface was manually measured with a water level probe (Eijkelkamp Agrisearch Equipment, The Netherlands). At the DP sites, net ecosystem exchange (NEE) was measured with the same polycarbonate chambers described above under a range of ambient light levels (PPFD; $\mu \mathrm{mol} \mathrm{m} \mathrm{m}^{-2} \mathrm{~s}^{-1}$ ) prior to $R_{\text {eco }}$ measurements. NEE measurements were carried out between 08:00 and 18:00 GMT in the summer and between 09:00 and 15:00 GMT in the winter (three to eight measurements per collar per measurement day) to ensure that the maximum PPFD was reached at each measurement date. Artificial shading was used in the early morning to obtain low PPFD levels $\left(<100 \mu \mathrm{mol} \mathrm{m}^{-2} \mathrm{~s}^{-1}\right)$. PPFD was recorded from a sensor (PAR-1, PP Systems) located within the chamber. The portable $\mathrm{CO}_{2}$ analysers were regularly calibrated with a $\mathrm{CO}_{2}$ standard gas.

\subsubsection{Flux calculations}

Flux rates $\left(\mathrm{mg} \mathrm{CO}_{2}-\mathrm{C} \mathrm{m}^{-2} \mathrm{~h}^{-1}\right)$ were calculated as the linear slope of the $\mathrm{CO}_{2}$ concentration in the chamber headspace over time, with respect to the chamber volume, collar area and air temperature. A flux was accepted if the coefficient of determination $\left(r^{2}\right)$ was at least 0.90 . An exception was made in cases where the flux was close to 0 (mainly in wintertime when soil processes are typically slower) and the $r^{2}$ is always low (Alm et al., 2007b). In these cases the flux data were examined graphically, and fluxes with obvious non-linearity (due to chamber leakage, fan malfunction, etc.) were discarded. The remainder were accepted provided that some of the environmental variables measured at the same time (e.g. soil temperature) were sufficiently low to account for the low flux values (Wilson et al., 2013a). In this study, we followed the sign convention whereby positive values indicated a $\mathrm{CO}_{2}-$ $\mathrm{C}$ flux from the peatland to the atmosphere (source) and negative values indicated a flux from the atmosphere to the peatland (sink). Gross primary production (GPP) was calculated as NEE minus $R_{\text {eco }}$ (Alm et al., 2007b), and the closest $R_{\text {eco }}$ flux value in time to a NEE flux value was used.

\subsubsection{Modelling}

Statistical and physiological response models (Alm et al., 2007b) were constructed and parameterised for each study site. Model evaluation was based on the following criteria; (a) statistically significant model parameters $(p<0.05)$, (b) lowest possible standard error of the model parameters and (c) highest possible coefficient of determination (adjusted $r^{2}$; see Laine et al., 2009). The basic $R_{\text {eco }}$ models, based upon the Arrhenius equation (Lloyd and Taylor, 1994), are nonlinear models related to soil temperature. GPP was related to PPFD using the Michaelis-Menten-type relationship that describes the saturating response of photosynthesis to light (Tuittila et al., 1999). GPP model coefficients and associated standard errors were estimated using the LevenbergMarquardt multiple non-linear regression technique (IBM SPSS Statistics for Windows, Version 21.0. Armonk, NY, USA). During model construction, the relationship between $R_{\text {eco }}$ or GPP and a range of independent environmental variables (recorded in conjunction with flux measurements) was tested. Only variables that increased the explanatory power of the model (i.e. improved $r^{2}$ values) were included. The models were accepted if the residuals were evenly scattered around 0 .

\subsubsection{Annual $\mathrm{CO}_{2}-\mathrm{C}$ balance}

The response functions estimated for $R_{\text {eco }}$ and GPP were used for the reconstruction of the annual $\mathrm{CO}_{2}-\mathrm{C}$ balance. $\mathrm{R}_{\text {eco }}$ fluxes were reconstructed for each collar in combination with an hourly time series of (1) $T_{5} \mathrm{~cm}$, (2) VMC (at DP3) recorded by the data loggers or (3) WT depths linearly interpolated from weekly measurements. The annual $\mathrm{CO}_{2}-\mathrm{C}$ balance $\left(\mathrm{g} \mathrm{C} \mathrm{m}^{-2} \mathrm{yr}^{-1}\right)$ was calculated for each sample plot by integrating the hourly $R_{\text {eco }}$ values over each 12 -month period. (Note: integration periods vary between study sites; see Table 1.) At the DP sites, GPP was reconstructed in combination with (1) PPFD values recorded by the weather station, (2) plot-specific modelled LAI and (3) an hourly time series of $T_{5 \mathrm{~cm}}$ (DP1only). At the DP sites, annual NEE was calculated as annual GPP plus annual $R_{\text {eco }}$.

\subsubsection{Statistical analysis}

The $\mathrm{CO}_{2}$-C flux data ( $R_{\text {eco }}$ for the IP sites and $R_{\text {eco }}$ and GPP for the DP sites) had a non-normal distribution, so the nonparametric Kruskal-Wallis $(p=0.05)$ and Mann-Whitney tests were used to test for differences between sites. Uncertainty in reconstructed annual $R_{\text {eco }}$ and GPP was calculated by summing up the maximum and minimum standard errors associated with each of the model parameters (e.g. Drösler, 2005; Elsgaard et al., 2012; Renou-Wilson et al., 2014). Uncertainty in the annual $R_{\text {eco }}$ or NEE estimate was calculated following the law of error propagation as the square root of the sum of the squared standard errors of GPP and $R_{\text {eco }}$ (IPCC, 2006).

\subsection{Peat fire emissions}

Around $5 \mathrm{~kg}$ (dry mass) of loose Irish Sphagnum moss peat (H2-H3 on the von Post decomposition scale) was used for measuring fire EFs. Subsamples of the peat were taken and placed in a $22 \times 12 \times 10 \mathrm{~cm}$ open-topped insulated chamber. The chamber was constructed from lightweight Celcon insulation blocks and was used to replicate natural surface combustion conditions, leaving only one surface of the peat exposed to open air and thereby reducing heat loss 
and oxygen exchange from the other surfaces, in accordance with the suggested peat combustion methodology of Rein et al. (2009). Each sample was dried in an oven overnight at $60^{\circ} \mathrm{C}$. In order to produce comparable replicates, the samples for the burning experiment had to be dried to an absolute dry base to increase ignition probability (Frandsen, 1997) and encourage pyrolysis (Rein et al., 2009). Following drying, the chamber and sample were placed in a fume cupboard under controlled airflow conditions and the peat was ignited using a coiled nichrome wire heated to $\sim 600^{\circ} \mathrm{C}$ and placed in contact with the surface of the peat. This also best represents natural ignition conditions (e.g. from a surface shrub fire), also in accordance with the methodology of Rein et al. (2009). Once ignited, each $1 \mathrm{~kg}$ sample proceeded to burn for $\sim 90 \mathrm{~min}$. The resulting smoke was continuously sampled using a pump and a $90 \mathrm{~cm}$ sample line with a funnel held $\sim 12 \mathrm{~cm}$ above the smouldering peat. The smoke was sampled into an $8.5 \mathrm{~L}$ infrared White (multipass) cell (Infrared Analysis, Inc.) where infrared spectra were collected using a Fourier transform infrared (FTIR) spectrometer. Analysis of the FTIR spectra was performed using the Multi-Atmospheric Layer Transmission (MALT) software (Griffith, 1996), yielding trace gas mole fractions inside the White cell, from which emissions factors may be calculated. A full description of how EFs may be calculated from FTIR measurements of gas mole fractions is given in Paton-Walsh et al. (2014) and Smith et al. (2014). Here we use the $\mathrm{C}$ mass balance approach to calculate $\mathrm{EFs}$ for $\mathrm{CO}_{2}$ and CO (Eq. (1) in Paton-Walsh et al., 2014). The C content of the peat (required for calculating EFs via the $\mathrm{C}$ mass balance approach) is assumed to be $53.3 \%$, as measured in Scottish Sphagnum moss peat (Cancellieri et al., 2012). For all other gas species considered in the study $\left(\mathrm{CH}_{4}\right.$, ethylene $\left(\mathrm{C}_{2} \mathrm{H}_{4}\right)$ ethane $\left(\mathrm{C}_{2} \mathrm{H}_{6}\right)$, methanol $\left.\left(\mathrm{CH}_{3} \mathrm{OH}\right), \mathrm{HCN}, \mathrm{NH}_{3}\right)$, we use their respective emission ratios to $\mathrm{CO}$ and the $\mathrm{EF}$ for $\mathrm{CO}$ to calculate EFs (via Eq. (5) in Paton-Walsh et al., 2014).

Combustion efficiency is a measure of the amount of fuel carbon released as $\mathrm{CO}_{2}$ and may be approximated using the modified combustion efficiency (MCE) formula, which requires only a measurement of $\mathrm{CO}$ and $\mathrm{CO}_{2}$ rather than all the C-containing gases (Yokelson et al., 2008):

$\mathrm{MCE}=\frac{\Delta \mathrm{CO}_{2}}{\Delta \mathrm{CO}_{2}+\Delta \mathrm{CO}}$

where $\Delta \mathrm{CO}_{2}$ and $\Delta \mathrm{CO}$ represent the elevated mixing ratios of these gases (the difference between mixing ratios measured in biomass burn emissions and those in the ambient air). MCE is often expressed as a percentage. Generally, an MCE lower than $0.9(90 \%)$ is considered a low-combustionefficiency burn (Lobert et al., 1991; Yokelson et al., 1996).

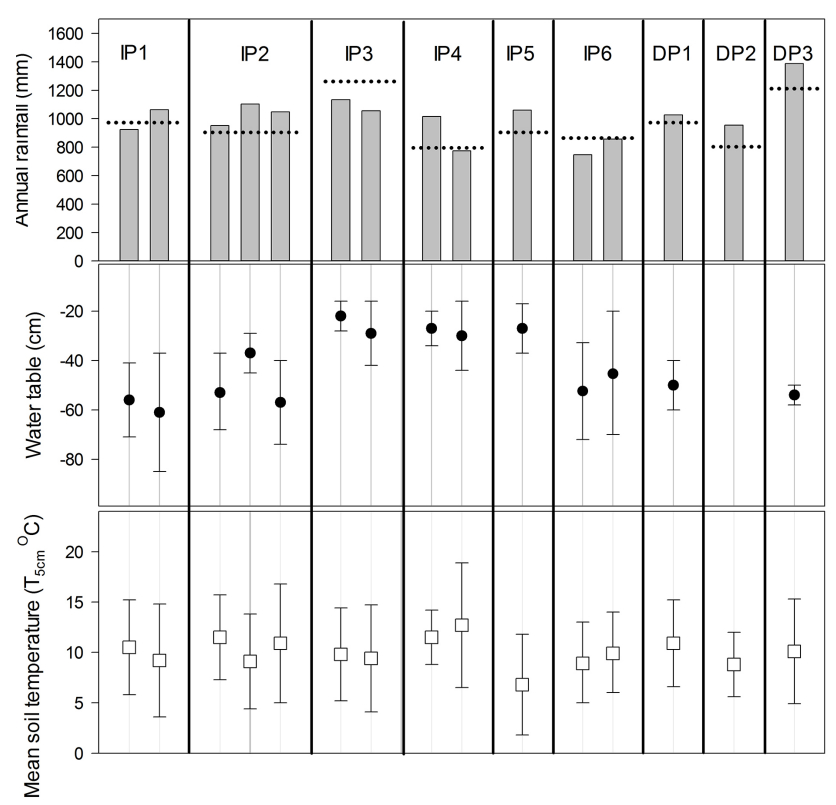

Figure 1. Annual rainfall $(\mathrm{mm})$, mean annual water tables $(\mathrm{cm})$, mean annual temperature $\left({ }^{\circ} \mathrm{C}\right)$ at $5 \mathrm{~cm}$ depths $\left(T_{5} \mathrm{~cm}\right)$ at sites IP1 (2 years), IP2 (3 years), IP3 (2 years), IP4 (2 years), IP5 (2 year), IP6 (2 years), DP1 (1 year), DP2 (1 year) and DP3 (1 year). Dotted horizontal line indicates 30-year mean rainfall at each site (19812010; Met Éireann, http://www.met.ie/, and Met Office UK, http: //www.metoffice.gov.uk). Error bars are standard deviations. Negative water table values indicate water level below the soil surface.

\section{Results}

\subsection{Environmental variables}

Annual rainfall varied between sites and between years (Fig. 1). The wettest site was DP3 $(1390 \mathrm{~mm})$ and the driest was IP6 $(746 \mathrm{~mm})$ in the first year of measurements at that site. All multi-year sites displayed interannual variation in rainfall with the largest differences observed in IP4 $(210 \mathrm{~mm}$ difference in annual rainfall between years). Annual rainfall at IP2, IP5, DP1, DP2 and DP3 was above the long-term average in all years. IP1 and IP4 were wetter than the long-term average in one of the years and drier in the other. IP3 and IP6 were drier than the long-term average. The mean annual water table was below $-20 \mathrm{~cm}$ at all sites in all years (Fig. 1). The deepest mean annual values were at IP1 $(-60 \mathrm{~cm})$ and the shallowest at IP3, 4 and $5(-25 \mathrm{~cm})$. Mean water table position tracked annual rainfall (i.e. higher rainfall resulted in higher water table positions) at all multi-year sites with the exception of IP1.

The highest mean annual soil temperature $\left(T_{5} \mathrm{~cm}\right)$ value $\left(12.7^{\circ} \mathrm{C}\right)$ was recorded at IP4 and the lowest at IP5 $\left(6.7^{\circ} \mathrm{C}\right)$, and interannual variation was evident in the multi-year sites (Fig. 1). The lowest hourly $T_{5} \mathrm{~cm}$ value $\left(-12.9^{\circ} \mathrm{C}\right)$ was recorded at IP5 and the highest $\left(28.4^{\circ} \mathrm{C}\right)$ at IP4 (Fig. 2). The proportion of hourly $T_{5} \mathrm{~cm}$ values less than $0^{\circ} \mathrm{C}$ ranged from 
0 (IP3) to $13.8 \%$ (IP5), and the proportion of values greater than $20^{\circ} \mathrm{C}$ ranged from 0.2 (IP5) to $5.3 \%$ (IP2; Fig. 2).

\subsection{On-site carbon dioxide fluxes}

At the IP sites, $R_{\text {eco }}$ fluxes ranged from 0 to $133 \mathrm{mg} \mathrm{CO}_{2}$ $\mathrm{C} \mathrm{m}^{-2} \mathrm{hr}^{-1}$ and differed significantly between sites (Fig. 3a; Kruskal-Wallis $H=98.59$ ). Site IP4 had significantly higher $R_{\text {eco }}$ flux values than all the other IP sites (Mann-Whitney $p<0.001)$ and IP5 had significantly lower flux values than IP2, IP4 and IP6 (Mann-Whitney $p<0.001$ ) but not IP1 and IP3 (Mann-Whitney $p=0.31$ ). At the DP sites, $R_{\text {eco }}$ fluxes ranged from 12 to $200 \mathrm{mg} \mathrm{CO}_{2}-\mathrm{C} \mathrm{m}^{-2} \mathrm{hr}^{-1}$, and there was a significant difference in $R_{\text {eco }}$ fluxes between the DP sites (Fig. 3b; Kruskal-Wallis $H=37.52$ ) but no significant difference between DP1 and DP2 (Mann-Whitney $p=0.075)$. $R_{\text {eco }}$ values differed significantly between the IP and DP sites (Kruskal-Wallis $H=395.22$ ). Measured NEE (at PPFD > $1000 \mu \mathrm{mol} \mathrm{m}{ }^{-2} \mathrm{~s}^{-1}$ ) ranged from 60 to $-325 \mathrm{mg} \mathrm{CO}_{2}-\mathrm{C} \mathrm{m}^{-2} \mathrm{hr}^{-1}$ at the DP sites and values differed significantly between sites (Fig. 3c; Kruskal-Wallis $H=90.82$ ).

\subsubsection{Modelling}

At sites IP6 and DP2, $T_{5 \mathrm{~cm}}$ was the sole explanatory variable in the $R_{\text {eco }}$ models (Eq. 2) and explained $32 \%$ and $42 \%$ respectively of the variability in fluxes. The addition of the water table to the $R_{\text {eco }}$ model (Eq. 3) slightly improved the explanatory power, and the model explained between 55 and $85 \%$ of the variability at IP1-4 and $69 \%$ at DP1. No relationship between $R_{\text {eco }}$ and WT was observed at DP3, but the addition of VMC (Eq. 4) also slightly improved the explanatory power of the model $(78 \%)$. At IP5, the data were too limited $(n=22)$ to construct a reliable model that satisfied the criteria outlined in Sect. 2.5.3. Instead, we calculated monthly mean values and integrated these values over the 12-month study period.

$$
\begin{aligned}
& R_{\mathrm{eco}}=a \cdot \exp \cdot\left[b\left(\frac{1}{T_{\mathrm{REF}}-T_{0}}-\frac{1}{T-T_{0}}\right)\right], \\
& R_{\mathrm{eco}}=a \cdot \exp \cdot\left[b\left(\frac{1}{T_{\mathrm{REF}}-T_{0}}-\frac{1}{T-T_{0}}\right)\right] \cdot \mathrm{WT}, \\
& R_{\mathrm{eco}}=a \cdot \exp \cdot\left[b\left(\frac{1}{T_{\mathrm{REF}}-T_{0}}-\frac{1}{T-T_{0}}\right)\right] \cdot \mathrm{VMC},
\end{aligned}
$$

where $R_{\text {eco }}$ is ecosystem respiration, $T_{\mathrm{REF}}$ is reference temperature set at $283.15 \mathrm{~K}, T_{0}$ is the (minimum) temperature at which respiration reaches 0 and is set here at $227.13 \mathrm{~K}, T$ is the soil temperature at $5 \mathrm{~cm}$ depth, WT is water table depth, VMC is volumetric moisture content, and $a$ and $b$ are fitted model parameters.

A strong relationship was observed between GPP and PPFD at the DP sites. It was the sole explaining variable at DP2 (Eq. 5), where it accounted for $70 \%$ of the variation. The addition of LAI (Eq. 6) increased the explanatory power
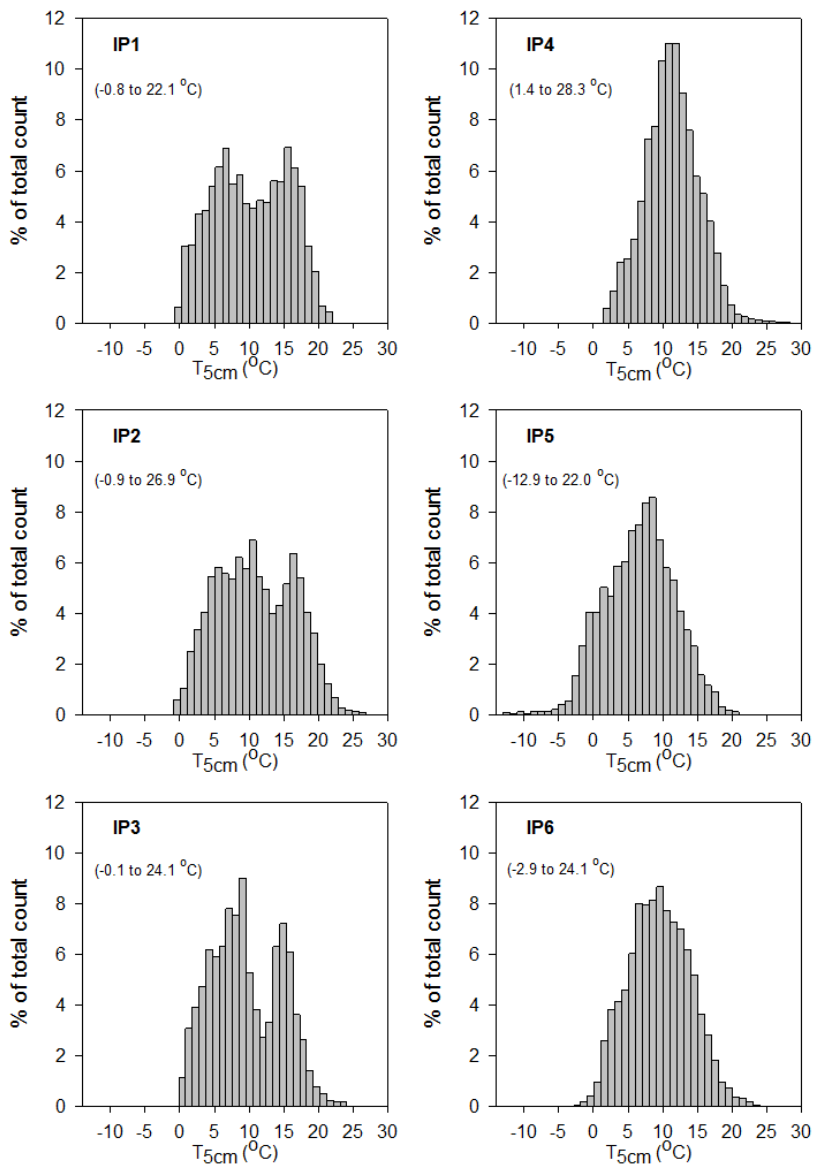

Figure 2. Frequency distribution of soil temperature at $5 \mathrm{~cm}$ depth $\left(T_{5 \mathrm{~cm}}\right)$ at sites IP1-6 shown as a percentage $(\%)$ of total count. Measured temperature range $\left({ }^{\circ} \mathrm{C}\right)$ at each site shown in parenthesis.

of the GPP model at DP3 (59\%), and the addition of LAI and $T_{5} \mathrm{~cm}$ resulted in $62 \%$ of the variation being explained at DP1.

$\mathrm{GPP}=P_{\max }\left(\frac{\mathrm{PPFD}}{\mathrm{PPFD}+k_{\mathrm{PPFD}}}\right)$,
$\mathrm{GPP}=P_{\max }\left(\frac{\mathrm{PPFD}}{\mathrm{PPFD}+k_{\mathrm{PPFD}}}\right) \cdot \mathrm{LAI}$,
$\mathrm{GPP}=P_{\max }\left(\frac{\mathrm{PPFD}}{\mathrm{PPFD}+k_{\mathrm{PPFD}}}\right) \cdot \mathrm{LAI} \cdot T_{5 \mathrm{~cm}}$,

where GPP is gross primary productivity, $P_{\max }$ is maximum photosynthesis, PPFD is photosynthetic photon flux density, $k_{\text {PPFD }}$ is the PPFD value at which GPP reaches half its maximum, LAI is leaf area index, and $T_{5 \mathrm{~cm}}$ is soil temperature at depth of $5 \mathrm{~cm}$.

\subsubsection{Annual $\mathrm{CO}_{2}-\mathrm{C}$ balance}

The annual $\mathrm{CO}_{2}-\mathrm{C}$ balance varied both spatially (between sites) and temporally (multi-year sites; Figs. 4 and 5). At the IP sites, emissions ranged from 93 (IP5) to $304 \mathrm{~g} \mathrm{CO}_{2-}$ 

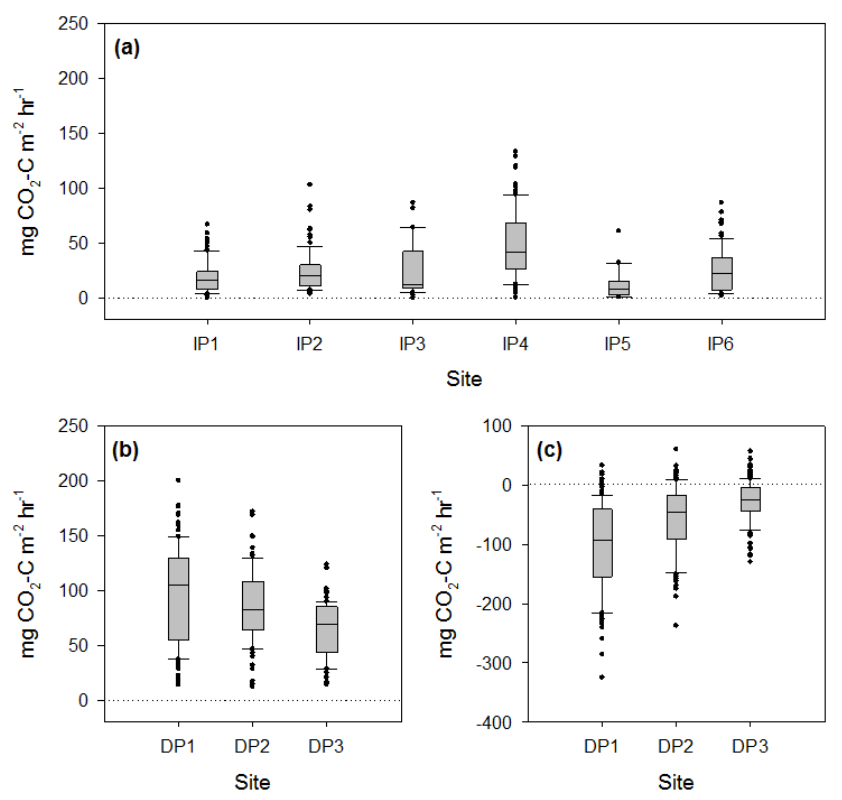

Figure 3. (a) Ecosystem respiration $\left(R_{\mathrm{eco}} ; \mathrm{mg} \mathrm{CO}_{2}-\mathrm{Cm}^{-2} \mathrm{hr}^{-1}\right)$ at sites IP1-6, (b) $R_{\text {eco }}\left(\mathrm{mg} \mathrm{CO}_{2}-\mathrm{C} \mathrm{m}^{-2} \mathrm{hr}^{-1}\right)$ at sites DP1-3 and (c) net ecosystem exchange (NEE; $\mathrm{mg} \mathrm{CO}_{2}-\mathrm{C} \mathrm{m}^{-2} \mathrm{hr}^{-1}$ ) when PPFD> $1000 \mu \mathrm{mol} \mathrm{m}^{-2} \mathrm{~s}^{-1}$ at sites DP1-3. Positive values indicate $\mathrm{CO}_{2}-\mathrm{C}$ flux from the peatland to the atmosphere (source) and negative values indicate $\mathrm{CO}_{2}-\mathrm{C}$ flux from the atmosphere to the peatland (sink). The 10th and 90th percentile are indicated by the bars, the 25th and 75th percentiles with the top and bottom of the box and the median value by the centre line.

$\mathrm{C} \mathrm{m}^{-2} \mathrm{yr}^{-1}$ (IP4). Annual emissions varied considerably within the multi-year sites, where the coefficient of variation values ranged from 4 (IP1) to $20 \%$ (IP2). As would be expected given the close relationship observed between soil temperature and $\mathrm{CO}_{2}-\mathrm{C}$ fluxes, a noticeable increase in modelled $\mathrm{CO}_{2}-\mathrm{C}$ emissions was observed during the summer months at all sites (Fig. 4), although the rate of the increase varied somewhat in strength between years at the multi-year sites as a function of measured $T_{5} \mathrm{~cm}$ and WT (where applicable). At the DP sites (Fig. 5), annual GPP and $R_{\text {eco }}$ were highest at DP1 (-526 and $702 \mathrm{~g} \mathrm{CO}_{2}-\mathrm{C} \mathrm{m}^{-2} \mathrm{yr}^{-1}$ respectively), intermediate at DP2 $\left(-484\right.$ and $687 \mathrm{~g} \mathrm{CO}_{2}$ $\mathrm{C} \mathrm{m}^{-2} \mathrm{yr}^{-1}$ respectively) and lowest at DP3 (-319 and $434 \mathrm{~g} \mathrm{CO}_{2}-\mathrm{C} \mathrm{m}^{-2} \mathrm{yr}^{-1}$ respectively). The DP sites were a net annual $\mathrm{CO}_{2}-\mathrm{C}$ source, with the highest emissions observed at DP2 $\left(203 \mathrm{~g} \mathrm{CO}_{2}-\mathrm{C} \mathrm{m}^{-2} \mathrm{yr}^{-1}\right)$, intermediate emissions at DP1 $\left(176 \mathrm{~g} \mathrm{CO}_{2}-\mathrm{Cm}^{-2} \mathrm{yr}^{-1}\right)$ and lowest emissions at DP3 $\left(114 \mathrm{~g} \mathrm{CO}_{2}-\mathrm{C} \mathrm{m}^{-2} \mathrm{yr}^{-1}\right)$. Estimated emissions from heterotrophic respiration $\left(R_{\mathrm{H}}\right)$ at DP1 were $344 \mathrm{~g} \mathrm{CO}_{2}$ $\mathrm{C} \mathrm{m}^{-2} \mathrm{yr}^{-1}$, which equates to $49 \%$ of $R_{\mathrm{eco}}$ at that site. Applying this proportional value to the other DP sites, we estimate $R_{\mathrm{H}}$ emissions to be 337 and $213 \mathrm{~g} \mathrm{CO}_{2}-\mathrm{C} \mathrm{m}^{-2} \mathrm{yr}^{-1}$ at DP2 and DP3 respectively.
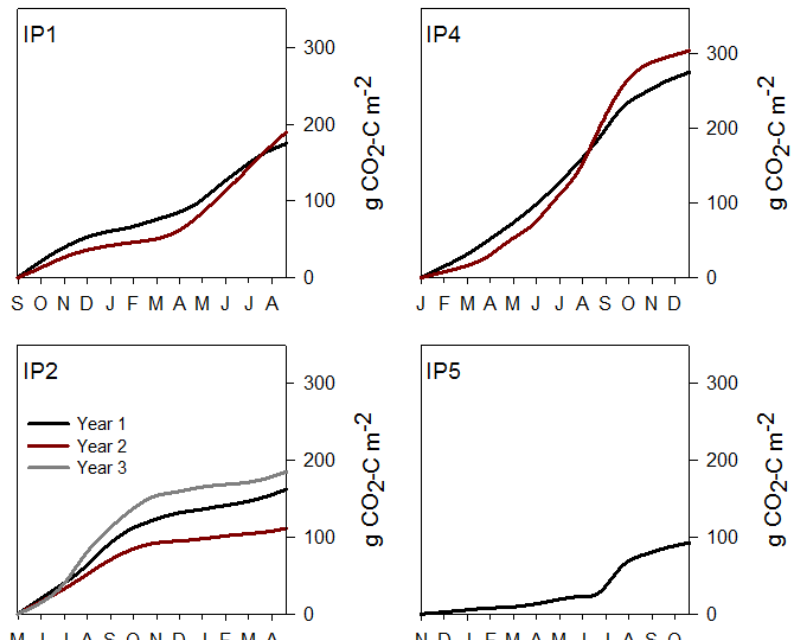

$M J J A S O N D J F M A$
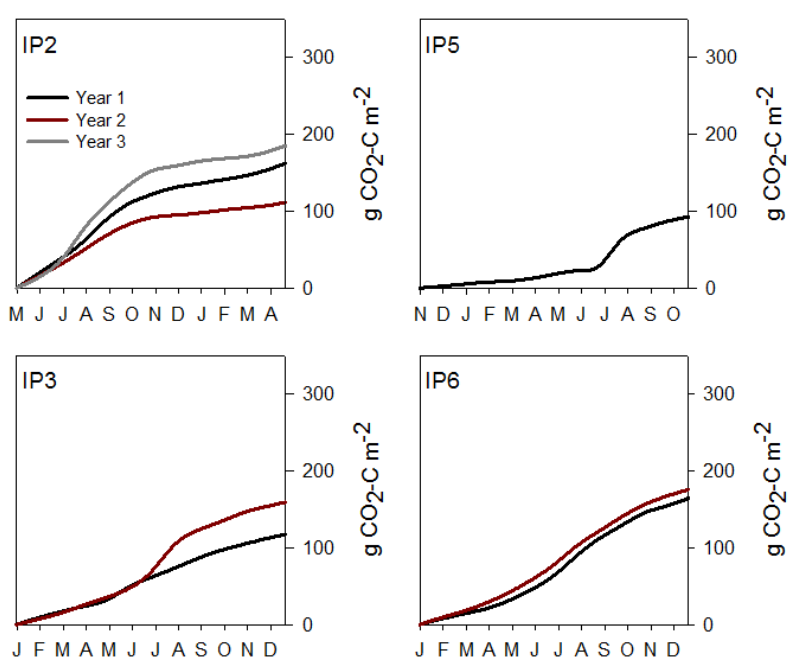

Figure 4. Annual cumulative ecosystem respiration $\left(R_{\mathrm{eco}}: \mathrm{g} \mathrm{CO}_{2}\right.$ $\mathrm{C} \mathrm{m}^{-2}$ ) at sites IP1-6. Positive values indicate $\mathrm{CO}_{2}-\mathrm{C}$ flux from the peatland to the atmosphere (source). Value at end of the curve indicates the total annual $R_{\text {eco }}$ value. Brown line indicates year 1, black line year 2 and grey line year 3 of the study at the individual sites. Note the differences in integration period between sites ( $x$ axis).

\subsection{Drivers of annual $\mathrm{CO}_{2}-\mathrm{C}_{\text {on }}$ site}

No relationships were observed between annual $\mathrm{CO}_{2}-\mathrm{C}$ balances (NEE) and nutrient concentrations, water table levels (average, maximum or minimum) or the von Post scale at either the IP or DP $(p>0.05)$ sites. A strong relationship $\left(r^{2}=0.63\right)$ between average soil temperature at $5 \mathrm{~cm}$ depth and $R_{\text {eco }}$ was very evident across the IP sites (Fig. 6); the highest annual emissions and highest average soil temperatures were associated with IP4 and the lowest with IP5. The variation in NEE between the DP sites appeared to be related to differences in LAI (Fig. 6); however, the number of sites was very small $(n=3)$ and some caution must be used in this regard.

\subsection{Emission factors}

Using a single mean value for each multi-year site and for its associated uncertainty (IPCC, 2014), an EF was calculated for each land use category. The derived EFs for the IP and DP sites were $1.70( \pm 0.47)$ and $1.64( \pm 0.44) \mathrm{tCO}_{2}-\mathrm{C} \mathrm{ha}^{-1} \mathrm{yr}^{-1}$ respectively (Table 2 ). The $95 \%$ confidence intervals associated with the derived EFs were $\pm 28 \%$ and $\pm 26 \%$ for the IP 


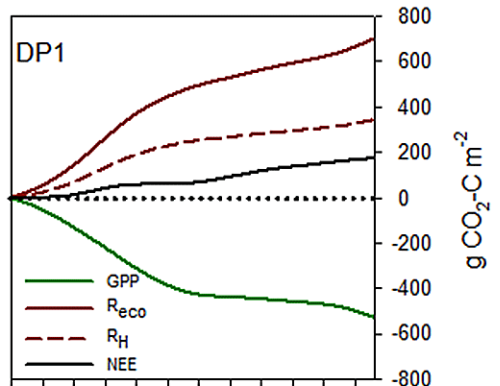

$M J J A S O N D J F M A$

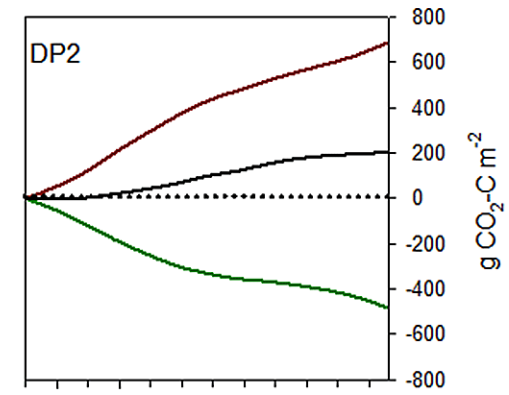

$M$ J J A S O N D J F M A

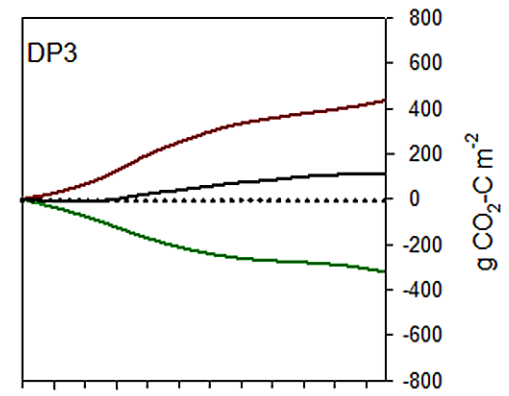

$A M J J A S O N D J F M$
O)
0
0
0
0

O
0
0
0
0

Figure 5. Annual cumulative gross primary productivity (GPP: $\left.\mathrm{g} \mathrm{CO}_{2}-\mathrm{C} \mathrm{m}^{-2}\right)$, ecosystem respiration $\left(R_{\mathrm{eco}}: \mathrm{g} \mathrm{CO}_{2}-\mathrm{C} \mathrm{m}^{-2}\right.$ ), heterotrophic respiration $\left(R_{\mathrm{H}}\right.$ : site DP1 only) and net ecosystem exchange (NEE: $\mathrm{g} \mathrm{CO}_{2}-\mathrm{Cm}^{-2}$ ) at sites DP1-3. Positive values indicate $\mathrm{CO}_{2}-\mathrm{C}$ flux from the peatland to the atmosphere (source) and negative values indicate $\mathrm{CO}_{2}-\mathrm{C}$ flux from the atmosphere to the peatland (sink). Value at end of the curve indicates the total annual value for each component. Note the differences in integration period between sites ( $x$ axis).

and the DP sites respectively. There was no significant difference in the EF values between the IP and DP sites $(p=0.90)$.

\subsection{Peat fire emission factors}

Mean MCE and EFs with their standard deviations for eight trace gas species were calculated from measurements of five Irish Sphagnum moss peat samples (Table 3). The peat burned with a mean MCE of $0.837( \pm 0.019)$ typical of smouldering combustion (e.g. Yokelson et al., 1996; Bertschi et al., 2003). Emissions of $\mathrm{CO}_{2}$ amounted to 1346 $( \pm 31) \mathrm{g} \mathrm{CO}_{2} \mathrm{~kg}^{-1}$ of dry fuel burned or $342( \pm 8) \mathrm{g} \mathrm{CO}_{2}-\mathrm{C}$. Other carbonaceous emissions amounted to $218 \mathrm{~g} \mathrm{CO} \mathrm{kg}^{1}$,

Table 2. Emission factors (tonnes $\mathrm{CO}_{2}-\mathrm{Cha}^{-1} \mathrm{yr}^{-1}$ ) for sites IP16 and DP1-3. Uncertainties are $95 \%$ confidence intervals.

\begin{tabular}{lccc}
\hline Site & $\begin{array}{c}\mathrm{CO}_{2}-\mathrm{C} \\
\left(\mathrm{tha}^{-1} \mathrm{yr}^{-1}\right)\end{array}$ & $\begin{array}{c}95 \% \text { confidence interval } \\
\left(\mathrm{tha}^{-1} \mathrm{yr}^{-1}\right)\end{array}$ \\
\hline IP1 & 1.82 & 1.75 & 1.89 \\
IP2 & 1.53 & 1.37 & 1.60 \\
IP3 & 1.38 & 1.25 & 1.52 \\
IP4 & 2.86 & 2.65 & 3.06 \\
IP5 & 0.93 & 0.59 & 1.27 \\
IP6 & 1.70 & 1.43 & 1.98 \\
Emission & $\mathbf{1 . 7 0}$ & $\mathbf{1 . 2 3}$ & $\mathbf{2 . 1 7}$ \\
factor & & & \\
DP1 & 1.76 & 1.59 & 1.99 \\
DP2 & 2.03 & 1.73 & 2.30 \\
DP3 & 1.14 & 0.85 & 1.41 \\
Emission & $\mathbf{1 . 6 4}$ & $\mathbf{1 . 2 2}$ & $\mathbf{2 . 0 6}$ \\
factor & & & \\
\hline
\end{tabular}

$8.35 \mathrm{~g} \mathrm{CH}_{4} \mathrm{~kg}^{-1}, 1.74 \mathrm{~g} \mathrm{C}_{2} \mathrm{H}_{4} \mathrm{~kg}^{-1}, 1.53 \mathrm{~g} \mathrm{C}_{2} \mathrm{H}_{6} \mathrm{~kg}^{-1}$, and $0.60 \mathrm{~g} \mathrm{CH}_{3} \mathrm{OH} \mathrm{kg}{ }^{-1}$ of dry fuel burned. Emissions of the nitrogenous compounds amounted to $2.21 \mathrm{~g} \mathrm{HCN} \mathrm{kg}^{-1}$, and $0.73 \mathrm{~g} \mathrm{NH}_{3} \mathrm{~kg}^{-1}$.

\section{Discussion}

There is a very wide range in reported $\mathrm{CO}_{2}$ emissions from both active and abandoned peat extraction areas in the literature (Fig. 7). Much of this variation can be attributed to differences in climate, drainage level, peat type, peat extraction methods and the end use of the peat and, as such, provides a useful framework to examine the variations in this study.

\subsection{Effects of climate}

While the study sites in this paper are all located within the temperate zone, considerable variation in $\mathrm{CO}_{2}-\mathrm{C}$ emissions was evident. Given that all the sites are drained to a similar depth (Fig. 1), it is not surprising that the variation in emissions appeared to be controlled largely by differences in soil temperatures between the sites (Fig. 6). The coldest site in terms of mean soil temperatures and lowest in terms of annual emissions was Muirhead Moss (IP5) in north-eastern Scotland. Although rainfall and site water table levels were similar to the other sites, soil temperatures at this site remained below $0{ }^{\circ} \mathrm{C}$ for a high proportion $(\sim 14 \%)$ of the year and are likely to have resulted in a slowdown of extracellular enzymatic diffusion (Davidson and Janssens, 2006), reduced microbial activity (Fenner et al., 2005) and consequently lower rates of $\mathrm{CO}_{2}$ production (Basiliko et al., 2007). Indeed, it is likely that our value of $0.93 \mathrm{tCO}_{2}-\mathrm{C} \mathrm{ha}^{-1} \mathrm{yr}^{-1}$ at this site may be an overestimation given that it was calculated from monthly mean values that were measured during daytime hours (highest daily temperatures). As much of the peat- 
Table 3. Mean modified combustion efficiency (MCE) and emission factors $\left(\mathrm{g} \mathrm{kg}^{-1}\right.$ dry fuel burned) reported by this study and those for the same trace gases reported by previous studies of temperate or boreal peat (Yokelson et al. 1997; Stockwell et al. 2014). The mean and standard deviation of the emission factor is calculated from individual sample burns; nr: not reported.

\begin{tabular}{|c|c|c|c|c|}
\hline \multirow[b]{2}{*}{ Trace gas } & \multicolumn{4}{|c|}{ Emission factor ( $\mathrm{g} \mathrm{kg}^{-1}$ dry fuel burned) } \\
\hline & $\begin{array}{r}\text { Irish Sphagnum } \\
\text { moss peat } \\
\text { (this study) }\end{array}$ & $\begin{array}{r}\text { Canadian } \\
\text { boreal peat } \\
\text { Stockwell et al. }(2014)\end{array}$ & $\begin{array}{r}\text { North Carolina } \\
\text { temperate peat } \\
\text { Stockwell et al. (2014) }\end{array}$ & $\begin{array}{r}\text { Alaska and Minnesota } \\
\text { peat } \\
\text { Yokelson et al. (1997) }\end{array}$ \\
\hline MCE & $0.837 \pm 0.019$ & $0.805 \pm 0.009$ & $0.726 \pm 0.009$ & $0.809 \pm 0.033$ \\
\hline $\mathrm{CO}_{2}$ & $1346 \pm 31$ & $1274 \pm 19$ & $1066 \pm 287$ & $1395 \pm 52$ \\
\hline $\mathrm{CO}$ & $218 \pm 22$ & $197 \pm 9$ & $276 \pm 139$ & $209 \pm 68$ \\
\hline $\mathrm{CH}_{4}$ & $8.35 \pm 1.3$ & $6.25 \pm 2.17$ & $10.9 \pm 5.3$ & $6.85 \pm 5.66$ \\
\hline $\mathrm{C}_{2} \mathrm{H}_{4}$ & $1.74 \pm 0.23$ & $0.81 \pm 0.29$ & $1.27 \pm 0.51$ & $1.37 \pm 0.51$ \\
\hline $\mathrm{C}_{2} \mathrm{H}_{6}$ & $1.53 \pm 0.17$ & $\mathrm{nr}$ & $\mathrm{nr}$ & $\mathrm{nr}$ \\
\hline $\mathrm{CH}_{3} \mathrm{OH}$ & $0.60 \pm 0.87$ & $0.75 \pm 0.35$ & $2.83 \pm 2.87$ & $4.04 \pm 3.43$ \\
\hline $\mathrm{HCN}$ & $2.21 \pm 0.35$ & $1.77 \pm 0.55$ & $4.45 \pm 3.02$ & $5.09 \pm 5.64$ \\
\hline $\mathrm{NH}_{3}$ & $0.73 \pm 0.50$ & $2.21 \pm 0.24$ & $1.87 \pm 0.37$ & $8.76 \pm 13.76$ \\
\hline
\end{tabular}
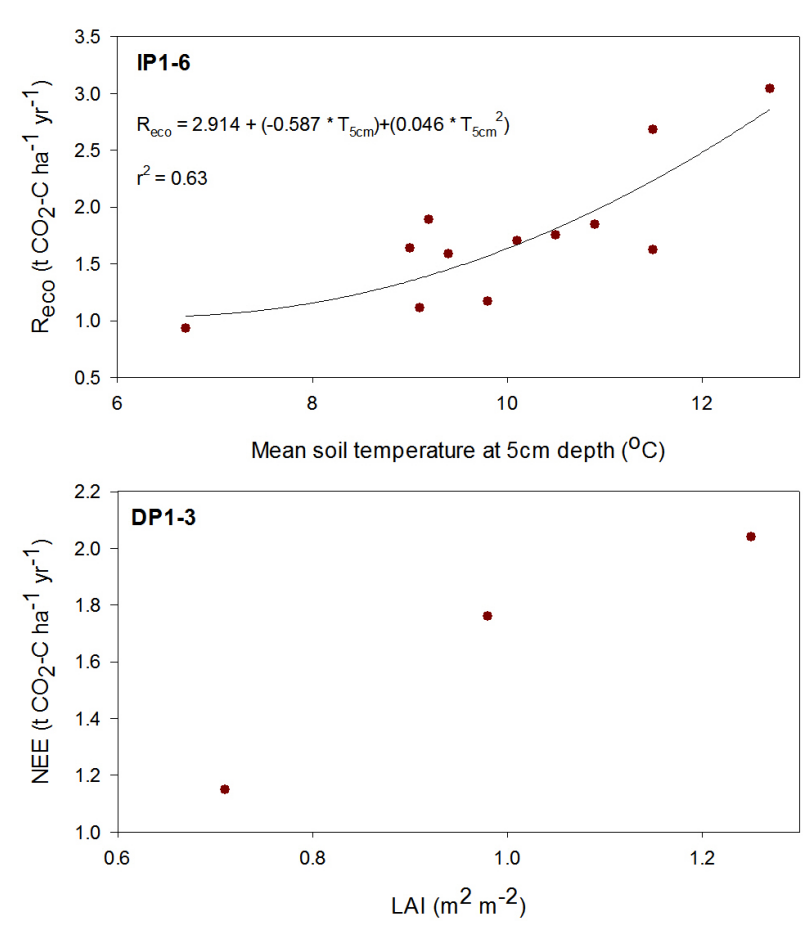

Figure 6. Relationship between (a) ecosystem respiration $\left(R_{\text {eco }}\right.$ : $\left.\mathrm{tCO}_{2}-\mathrm{Cha}^{-1} \mathrm{yr}^{-1}\right)$ and mean soil temperature $\left({ }^{\circ} \mathrm{C}\right)$ at $5 \mathrm{~cm}$ depth at the IP sites and (b) net ecosystem exchange $\left(\mathrm{NEE}\right.$ : $\mathrm{tCO}_{2}$ $\mathrm{Cha}^{-1} \mathrm{yr}^{-1}$ ) and leaf area index (LAI: $\mathrm{m}^{2} \mathrm{~m}^{-2}$ ). Circles indicate an annual value.

lands in Scotland fall within the same temperature regime (Chapman and Thurlow, 1998), $\mathrm{CO}_{2}-\mathrm{C}$ emissions data from a wider range of peat extraction sites in this region might significantly refine our EF derivation.

At the other end of the spectrum, the highest emissions and soil temperatures were observed at Turraun (IP4) in the Irish Midlands. Data from this site had been previously re- ported by Wilson et al. (2007). In this study, we only utilised $\mathrm{CO}_{2}-\mathrm{C}$ flux data from plots where the mean annual water table position was deeper than $-20 \mathrm{~cm}$. This resulted in a higher mean value (taken over 2 years) in this current study. Three of the IP sites in the ROI are located in the Midlands where more "extremes" in climate are generally experienced (lower winter temperatures, higher summer temperatures) than along the western coast (IP3). However, during this study, winter temperatures at all the ROI sites seldom decreased below $0{ }^{\circ} \mathrm{C}$ (Fig. 3) and the proportion of hourly temperatures higher than $20^{\circ} \mathrm{C}$ was somewhat similar between the sites. Although, Little Woolden Moss (IP6) received the lowest annual rainfall of all sites in year 1 of the study at that site (Fig. 1), mean annual soil temperatures were in the midrange of the nine study sites, hourly $T_{5 \mathrm{~cm}}$ values were normally distributed (Fig. 3) and $\mathrm{CO}_{2}-\mathrm{C}_{\mathrm{on}}$ site emissions were close to the derived EF value of $1.70 \mathrm{tCO}_{2}-\mathrm{Cha}^{-1} \mathrm{yr}^{-1}$ (Table 2).

The DP sites are all located in the ROI and within a $35 \mathrm{~km}$ radius, but considerable variation in annual rainfall was apparent during this study (Fig. 1), with DP3 (the furthest west) receiving the highest rainfall of all sites in the study (on average $34 \%$ more rainfall than at the other DP sites). The eastwest rainfall gradient in the ROI is well documented and coincides with a change in peatland types (i.e. raised bogs to Atlantic blanket bogs). This climatic variation is reflected in the annual $R_{\text {eco }}$ values, which were similar at DP1 and DP2 but much lower at DP3 (Fig. 5). There is an established relationship between rainfall amount and the moisture content of peat (Price and Schlotzhauer, 1999; Strack and Price, 2009). For the sites located in high-rainfall areas, such as DP3, there may be a suppression of aerobic microbial activity within the peat matrix, and as a consequence $R_{\text {eco }}$ values may be lower than would be expected for a drained peat soil. Indeed, at some of these sites, occult precipitation (e.g. dew and fog droplets) may also contribute significantly to higher levels of 


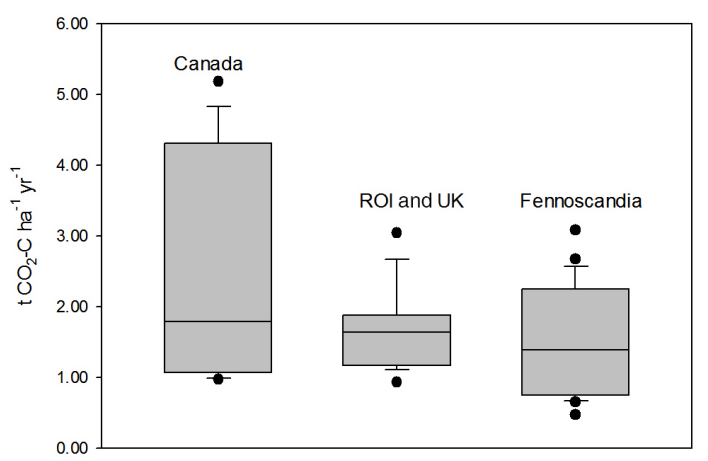

Figure 7. Carbon dioxide emissions $\left(\mathrm{tCO}_{2}-\mathrm{Cha}^{-1} \mathrm{yr}^{-1}\right)$ from peatlands managed for extraction in Canada, the ROI and the UK (this study) and Fennoscandia. The 10th and 90th percentile are indicated by the bars, the 25th and 75th percentiles with the top and bottom of the box and the median value by the centre line. (Data for Canada and Fennoscandia taken from the following studies; Tuittila and Komulainen, 1995; Sundh et al., 2000; Waddington et al., 2002; Glatzel et al., 2003; McNeil and Waddington, 2003; Tuittila et al., 2004; Cleary et al., 2005; Alm et al., 2007a; Shurpali et al., 2008; Waddington et al., 2010; Järveoja et al., 2012; Mander et al., 2012; Salm et al., 2012; Strack et al., 2014.) Where studies reported seasonal fluxes (typically May to October), these were converted to annual fluxes by assuming that $15 \%$ of the flux occurs in the nongrowing season (Saarnio et al., 2007).

soil moisture (Lindsay et al., 2014. During the growing season, the transpiration process is also likely to play a role in determining the moisture content of the peat within the rooting zone $(\sim 20 \mathrm{~cm}$ depth$)$ at these vegetated sites. Moisture losses are likely to be accentuated on sunny days when air and soil temperatures are high, when LAI values are highest (midsummer) and when vapour pressure deficit is not a limiting factor. As $\mathrm{CO}_{2}$ emissions were closely correlated to soil temperature at $5 \mathrm{~cm}$ depth, reduced moisture content in this zone is likely to stimulate aerobic microbial activity. Annual GPP showed a similar trend to annual $R_{\text {eco }}$ at these vegetated DP sites. GPP is strongly controlled by the amount of light received by the plants (i.e. PPFD levels and LAI) and the efficiency with which the plants use it. PPFD values (data not shown) and the vegetation composition were broadly similar during the sampling periods, which would seem to indicate that LAI is the driver of both productivity and therefore NEE at these sites (Fig. 6). However, variations in LAI are likely to be the result of subtle differences in a number of other variables (e.g. nutrient status, site management) that were not captured in our measurements.

\subsection{Effects of drainage level}

While a close relationship between WT position and $\mathrm{CO}_{2}-$ $\mathrm{C}$ emissions has been established in some peatland studies (Silvola et al., 1996; Blodau and Moore, 2003; Blodau et al., 2004), soil temperature proved to be the strongest determi- nant of $\mathrm{CO}_{2}-\mathrm{C}_{\text {on-site }}$ emissions at our sites and this relationship has also been observed by other studies in peat extraction areas (e.g. Shurpali et al., 2008; Mander et al., 2012; Salm et al., 2012). While the addition of WT or VMC improved the performance of the $R_{\text {eco }}$ models at some of the sites, the improvement was only slight and this is likely due to the fairly narrow range of WT and VMC values recorded over the course of the 12-month study (e.g. the range in VMC values at DP3 was between 56 and $64 \%$ ). Therefore, optimum WT and VMC levels for respiration may not have been encountered. The $R_{\text {eco }}$ models used here are only valid for the data that were measured over the course of the study at each site and cannot be readily extrapolated beyond the range of that data. For those sites where the water table did not appear to influence $R_{\text {eco }}$ dynamics it may be that fluctuations in WT level were missed with the interpolation approach and $\mathrm{CO}_{2}-\mathrm{C}$ flux measurement regimes that we employed here, although these methodologies have been widely used elsewhere (Riutta et al., 2007; Soini et al., 2010; Renou-Wilson et al., 2014). Instead, it is probable that our results reflect the complexity of the relationship between $R_{\text {eco }}$ and WT in very dry soils as outlined by Lafleur et al. (2005), where factors such as a stable, low surface soil moisture content, and decreased porosity (i.e. limited oxygen availability) at the depths at which the WT is mainly located ensure that when $\mathrm{CO}_{2}-\mathrm{C}$ fluxes are measured, the WT is deeper than the zone where it has a discernible impact on $R_{\text {eco }}$ (Juszczak et al., 2013). As such, the soil temperature regime at these sites may act as a "proxy" for drainage level (i.e. higher soil temperatures are likely to occur in conjunction with deeper water table levels and vice versa; Mäkiranta et al., 2009).

\subsection{Peat characteristics}

Industrial peat extraction involves the removal of surface vegetation and results in the exposure of decomposed peat at the surface. The level of decomposition in the peat is related to depth and as extraction proceeds, the more highly decomposed peat is exposed. The peat at industrial extraction sites tends to have a lower aerobic $\mathrm{CO}_{2}$ production potential than at natural sites, for example, due to differences in substrate and nutrient availability, a more extreme physical environment (Glatzel et al., 2004) and reduced labile organic matter supply in the absence of plant communities (i.e. priming). In our study, the C content (with the exception of DP2) was similar across all sites (Table 1). Although, Glatzel et al. (2004) noted that $\mathrm{CO}_{2}$ production was negatively correlated with the von Post scale of decomposition, no correlation with annual $\mathrm{CO}_{2}-\mathrm{C}$ emissions was evident in our study $(p>0.05)$. Similarly, despite obvious differences in nitrogen content and $\mathrm{pH}$ values between IP sites, no relationships with $\mathrm{CO}_{2}$ fluxes were discerned. However, the residual peat at IP4 is strongly influenced by the close proximity of limestone parent material, as evidenced by high $\mathrm{pH}$ values and the lowest $\mathrm{C}: \mathrm{N}$ ratio (Table 1), and is highly minerotrophic. Given 
the high $\mathrm{CO}_{2}-\mathrm{C}$ emissions associated with this site, consideration should be given to disaggregation by nutrient type should more data become available in the future.

Organic matter quality has been closely linked to the soil respiration rate, with lower emission rates associated with the poorer-quality organic matter found at depth in drained peatlands (Leifeld et al., 2012). The lowest emissions at our sites occurred where the residual peat was either of Cyperaceous (IP3) or Sphagnum/cyperaceous (IP5) origin. However, while the slow decomposition rate of Sphagnum litter in comparison to other plant litter has been well documented (Verhoeven and Toth, 1995; Bragazza et al., 2007), there is insufficient data from our study sites to determine whether the limited relationship observed here between peat type and $\mathrm{CO}_{2}$-C emissions at our study sites is coincidental rather than causal.

\subsection{Effects of peat extraction methods and peat end use}

For peat utilised for horticulture, the more fibrous peat layers nearer the surface are extracted. This may result in the oxidation of more labile organic matter and may account for the very high emissions associated with Canadian peatlands, for example (Fig. 7), in comparison to countries where the deeper peat layers are extracted (Mander et al., 2012). However, the IP sites in this study are highly decomposed peat and have been abandoned for 30 years or more in some cases (e.g. IP4) and have remained unvegetated. It is possible that $\mathrm{CO}_{2}-\mathrm{C}$ emissions from active extraction areas may be higher than those derived in this study given that over the summer period the surface of the peat is regularly scarified and aerated. However, Salm et al. (2012) reported higher emissions from abandoned areas in comparison to active areas, although colonisation by vegetation in the former may have accentuated respiration losses. High annual $\mathrm{CO}_{2}-\mathrm{C}$ emissions following abandonment and recolonisation have also been reported by Strack and Zuback (2013) and are in close agreement with the $R_{\text {eco }}$ values reported here for the DP sites (Fig. 5).

We have estimated the contribution of heterotrophic respiration $\left(R_{\mathrm{H}}\right)$ to $R_{\text {eco }}$ at $49 \%$. Although this is based on measurements at a single site (DP1), it is within the range reported by other studies (Frolking et al., 2002; Moore et al., 2002; Shurpali et al., 2008). The $R_{\mathrm{H}}$ values measured at DP1 (Fig. 5) and estimated at DP2 are higher than the $R_{\text {eco }}$ values at the IP sites, which would indicate that decomposition of the belowground biomass (following clipping) and subsequent "priming" effects may contribute significantly to $\mathrm{CO}_{2}$ $\mathrm{C}$ dynamics at vegetated extraction sites. Furthermore, the methods employed to extract the peat at some of the DP sites (the peat is extruded onto the surface of the peatland from narrow openings made in the peat by a chain cutter) has led to the formation of deep fissures (ca. $4 \mathrm{~cm}$ wide and $>2 \mathrm{~m}$ deep) within the peat that may enhance oxidation throughout the peat profile. Nonetheless, fissures $(\mathrm{ca} .10 \mathrm{~cm}$ wide and $>1 \mathrm{~m}$ deep) that formed in the peat during climatically dry years and that were partially filled in during wetter and windier years were also observed at IP5, where the lowest annual emissions were observed.

\subsection{Fire emission factors}

The mean MCE reported here (0.837) is typical of smouldering combustion (e.g. Yokelson et al., 1996; Bertschi et al., 2003) and comparable with the reported range of MCE in other studies of high-latitude peats (Yokelson et al., 1997; Stockwell et al., 2014). Emission factors for $\mathrm{CO}_{2}$ and $\mathrm{CO}$ are also typical of smouldering combustion and similar to those from other peat studies, particularly Yokelson et al. (1997). As found in other studies of peat fire emissions, our measurements confirm that the $\mathrm{CH}_{4}$ EF for Irish peat is particularly high ( $8.35 \mathrm{~g} \mathrm{~kg}^{-1}$ dry fuel burned) when compared with other forms of biomass burning. Given the high global warming potential, where each gram of emitted $\mathrm{CH}_{4}$ is equivalent to $34 \mathrm{~g}$ of $\mathrm{CO}_{2}$ (100-year time horizon, IPCC, 2013), the $\mathrm{CH}_{4}$ emissions from Irish peat fires may account for over $12 \%$ of the $\mathrm{CO}_{2}$-equivalent emissions. This result emphasises the importance of understanding the full suite of trace gas emissions from biomass burning rather than focussing solely on $\mathrm{CO}_{2}$ and $\mathrm{CH}_{4}$ emissions. In general, the other EFs reported here lie within the range of variability observed by other peat burning studies, with the exception of $\mathrm{NH}_{3}$, which is particularly low, possibly as a result of the nitrogen-poor soils that are typical of Irish and UK blanket bogs. Here, we also report the first $\mathrm{C}_{2} \mathrm{H}_{6}$ EF for peat $\left(1.53 \pm 0.17 \mathrm{~g} \mathrm{~kg}^{-1}\right.$ dry fuel burned), similar in magnitude to $\mathrm{C}_{2} \mathrm{H}_{6}$ emissions from boreal forests (1.77 $\mathrm{g} \mathrm{kg}^{-1}$ dry fuel burned), according to Akagi et al. (2011). The use of prescribed fire in the UK to burn off old heather growth to encourage new growth (e.g. the muirburn practice) may not impact the underlying peat to any great extent, given that the practice is restricted to the October-April period when soil moisture conditions are highest. Emissions result from the burning of the woody aboveground biomass, and the underlying peat is generally unaffected. In contrast, wildfires typically occur during the summer months when temperatures are highest and moisture levels are low, resulting in the burning of both the vegetation and the peat itself. Indeed, recent work by Kettridge et al. (2015) has highlighted the vulnerability of drained peatlands, even at high latitudes, to increased risk of wildfire and subsequent vegetation changes.

\subsection{Implications for National Inventory reporting}

The ROI currently employs the 2006 GPG default value of $0.2 \mathrm{tCO}_{2}-\mathrm{Cha}^{-1}$ (nutrient-poor) in reporting of all peat extraction areas, and estimated emissions for 2012 (the most recent assessment year) were $9312 \mathrm{tCO}_{2}-\mathrm{C} \mathrm{yr}^{-1}$ (Table 4). In contrast, the approach in the UK has been to differentiate between peat extracted for fuel and horticulture and then 
applying the default EFs for nutrient-rich $\left(1.1 \mathrm{tCO}_{2}-\mathrm{C} \mathrm{ha}^{-1}\right)$ and nutrient-poor peat $\left(0.2 \mathrm{tCO}_{2}-\mathrm{Cha}^{-1}\right)$ respectively. For 2012, $\mathrm{CO}_{2}-\mathrm{C}$ emissions from UK extraction peatlands were estimated at $2118 \mathrm{tCO}_{2}-\mathrm{C} \mathrm{yr}^{-1}$ (Table 4).

Reported annual emissions are likely to increase considerably if the Tier 1 values in the IPCC Wetlands Supplement are adopted by inventory compilers. We estimate that emissions from peatlands managed for extraction will be approximately 16 and 10 times higher for the ROI and UK respectively (Table 4). The EFs derived in this study for $\mathrm{CO}_{2}-\mathrm{C}_{\mathrm{on}}$ site for both industrial and domestic peatlands (Table 2) are considerably lower than the Tier 1 value of $2.8 \mathrm{t}$ $\mathrm{CO}_{2}-\mathrm{Cha}^{-1} \mathrm{yr}^{-1}$ provided in the IPCC Wetlands Supplement (2014). Although the EFs derived in this study fall within the lower confidence margin of the Tier 1 range, our new EFs have a marked reduction in associated uncertainty. As the Tier 1 is a generic value based on published literature rather than a targeted measurement programme, it is naturally subject to a certain level of bias, which results when the underlying studies are not representative of management practices, climatic zones, or soil types in a particular region (Ogle et al., 2004) and may lead to either an over- or underestimation of $\mathrm{CO}_{2}-\mathrm{C}$ emissions. Given that no significant difference exists between the EFs derived for the IP and DP sites in this study, we propose a single $\mathrm{EF}$ for $\mathrm{CO}_{2}-\mathrm{C}_{\text {on-site }}$ of $1.68 \mathrm{tCO}_{2}-\mathrm{Cha}^{-1} \mathrm{yr}^{-1}$ to be applied to peatlands managed for extraction in the ROI and UK regardless of peat type. This EF value could be further disaggregated by regional climate, domestic peat extraction intensity (based on extraction rates) or by the end use of the peat (horticulture or energy) if more data become available. For the latter, it would be highly useful to determine quantitatively whether $\mathrm{CO}_{2}$ $\mathrm{C}_{\text {on-site }}$ emissions vary between the less decomposed residual peat utilised for horticulture and the more decomposed residual peat used for energy production. As the EFs derived in this study have come from sites located within the same "climatic" region, we feel that they are more appropriate for the ROI and the UK inventory purposes than either the 2006 GPG or the 2013 Wetlands Supplement. If the $\mathrm{CO}_{2}-\mathrm{C}_{\text {on }}$ site EFs derived from this study are used in annual NIRs, we estimate that annual emissions would be 9.5 and 6 times higher for the ROI and UK respectively, in comparison to the emissions calculated with the 2006 GPG Tier 1 value, and $40 \%$ lower than emissions calculated with the Wetlands Supplement EF.

As reported $\mathrm{CO}_{2}-\mathrm{C}_{\text {on-site }}$ emissions are henceforth likely to be much higher for any country that moves from the 2006 GPG to the 2013 Wetlands Supplement, some consideration of potential mitigation measures is required. Wetland Drainage and Rewetting is a new elective activity under Article 3.4 of the Kyoto Protocol (second commitment period) and applies to all lands that have been drained since 1990 and to all lands that have been rewetted since 1990. Countries that elect to report under this activity will also be able to claim $\mathrm{C}$ benefits from the rewetting of drained peatlands. In theory,
Table 4. Annual $\mathrm{CO}_{2}-\mathrm{C}$ emissions (in tonnes of $\mathrm{CO}_{2}-\mathrm{C} \mathrm{yr}^{-1}$ ) from peatlands managed for extraction in the ROI and UK calculated using the IPCC 2006 Good Practice Guidance (Tier 1 value: 0.2 and $1.1 \mathrm{tCO}_{2}-\mathrm{C} \mathrm{ha}^{-1} \mathrm{yr}^{-1}$ for nutrient-poor and nutrient-rich peatlands respectively), the IPCC 2013 Wetlands Supplement (Tier 1 value: $2.8 \mathrm{t} \mathrm{CO}_{2}-\mathrm{Cha}^{-1} \mathrm{yr}^{-1}$ ) and the Emission Factors derived in this study (Table 2). Areas (ha) and $\mathrm{CO}_{2}-\mathrm{C}$ emissions using the IPCC 2006 Good Practice Guidance values are taken from the 2014 National Inventory Reports (NIR) for the ROI (Duffy et al., 2014) and the UK (Webb et al., 2014).

\begin{tabular}{lrrrr}
\hline \multirow{2}{*}{ Country } & \multirow{2}{*}{ Area (ha) } & \multicolumn{3}{c}{ Emissions (tonnes $\mathrm{CO}_{2}-\mathrm{C} \mathrm{yr}^{-1}$ ) } \\
& & IPCC (2006) & IPCC (2013) & This study \\
\hline ROI & 52422 & 9312 & 146782 & 88069 \\
England & 4790 & 960 & 13412 & 8047 \\
Scotland & 1610 & 545 & 4508 & 2705 \\
Wales & 482 & 95 & 1350 & 810 \\
N. Ireland & 1030 & 518 & 2884 & 1730 \\
UK & 7912 & 2118 & 22154 & 13292 \\
\hline
\end{tabular}

this should provide an impetus for the rewetting of highly emitting land use categories such as peatlands managed for extraction, particularly as these areas will remain persistent long-term emission hotspots in the absence of rewetting actions (Waddington et al., 2002).

\subsection{Information gaps}

Greenhouse gas emissions from peatlands used for extraction are composed of (a) on-site emissions (i.e. from peat extraction areas, ditches and stockpiles) and (b) off-site emissions associated with waterborne losses and the use of the peat for energy or horticulture. In this paper, we have focused solely on the on-site $\mathrm{CO}_{2}-\mathrm{C}$ emissions from the peat extraction areas and GHG emissions from fire. However, C losses from other pathways may also be substantial. Research has shown that GHG emissions from on-site peat stockpiles and ditches are considerable (Alm et al., 2007a, and references therein). Currently, emissions data from stockpiles in the temperate zone are not available and the IPCC Wetlands Supplement does not provide a Tier 1 value and instead encourages countries to move to higher tiers in terms of reporting (IPCC, 2014). However, countries such as Finland have developed a Tier 2 approach in which EFs (including $\mathrm{CH}_{4}$ and $\mathrm{N}_{2} \mathrm{O}$ ) depend on regional weather and in which emissions from ditches and stockpiles are taken into account (Alm et al., 2007a; Lapveteläinen et al., 2007). The IPCC Wetlands Supplement provides Tier $1 \mathrm{EFs}$ for $\mathrm{CH}_{4}$ emissions from both peat extraction areas and from ditches. The value for the latter is particularly high $\left(542 \mathrm{~kg} \mathrm{CH}_{4} \mathrm{ha}^{-1} \mathrm{yr}^{-1}\right.$ expressed per unit area of ditch surface) and indicates the importance of this pathway in the full GHG balance (Evans et al., 2015). Similarly, $\mathrm{N}_{2} \mathrm{O}$ emissions have been shown to be significant from drained peatlands (Regina et al., 1996); yet despite this, there are only a small number of published studies and more 
research is critical in order to provide regionally specific EFs. While $\mathrm{CH}_{4}$ and $\mathrm{N}_{2} \mathrm{O}$ fluxes have been quantified at some of the sites in this study, the data are currently being processed with a view to publication in the future. In terms of the fire study, $\mathrm{N}_{2} \mathrm{O}$ is a difficult gas to measure using the FTIR setup employed in this study, as it can only be determined from spectra with very large enhancements of trace gases. This is because the $\mathrm{N}_{2} \mathrm{O}$ absorption occurs in a similar wave number region to both the $\mathrm{CO}_{2}$ and $\mathrm{CO}$ absorption bands (PatonWalsh et al., 2014). Paton-Walsh et al. (2014) could only determine $\mathrm{N}_{2} \mathrm{O}$ from two of their five open fires, whilst Smith et al. (2014), who used a similar set-up, failed to determine $\mathrm{N}_{2} \mathrm{O}$ from any of their 21 fires studied. In our study, we found that excess mole fractions of $\mathrm{N}_{2} \mathrm{O}$ could not be correlated to either $\mathrm{CO}_{2}$ or $\mathrm{CO}$ for the determination of emission ratios, precluding the calculation of EFs. One explanation for this is that $\mathrm{N}_{2} \mathrm{O}$ is predominantly a product of flaming combustion and is strongly correlated to $\mathrm{CO}_{2}$ (Paton-Walsh et al., 2014). The lack of flaming combustion in our peat burns probably explains our inability to detect significant excess $\mathrm{N}_{2} \mathrm{O}$ mole fractions.

Other pathways may be of equal importance. For example, the loss of POC from bare peat surfaces may be considerable where the surface is exposed and subject to wind or water erosion (Evans et al., 2006; Lindsay, 2010). While some of the windborne POC is likely to be deposited within the extraction field itself, a proportion undoubtedly leaves the peatland, although there are currently few data available to quantify losses from either wind or water erosion or the extent to which POC is converted to $\mathrm{CO}_{2}$ (IPCC, 2014). In addition, high losses of DOC from drained peatlands have been reported (Evans et al., 2015, and references therein). Although a Tier $1 \mathrm{EF}$ value for DOC is provided in the IPCC Wetlands Supplement, disaggregated by climate zone, with the assumption that $90 \%$ of the exported DOC is converted to $\mathrm{CO}_{2}$, there is an obvious need to quantify these losses on a regional basis given the high precipitation loads experienced by the ROI and the UK and the associated differences in peat type (Evans et al., 2015). Emissions from burning are not currently reported in either the ROI or UK inventory reports. The EF provided in the IPCC Wetlands Supplement for $\mathrm{CO}_{2}$ emissions associated with wildfire burning is similar to our value here (Table 3). Furthermore, given the high $\mathrm{CH}_{4}$ emissions associated with the burning of the peat that we have reported here (Table 3), and taking cognisance of the strong global warming potential of $\mathrm{CH}_{4}$, more research is urgently required to quantify this emission pathway, particularly under field conditions.

The provision of activity data for inventory reporting varies between the ROI and the UK, with the peat extraction industry the source of data in the former (Duffy et al., 2014), and a multi-source approach (Directory of Mines and Quarries, point locations with Google Earth imagery, scientific reports/papers) used in the latter (Webb et al., 2014). However, $\mathrm{CO}_{2}$ emissions from domestic peat extraction in the
ROI are not currently reported due to a lack of activity data and could potentially be very high (Wilson et al., 2013b). In the UK, areas under domestic extraction are included in the Grassland category but may be moved as the UK considers changes post-Wetlands Supplement. Determining to what degree peatlands have been affected by domestic peat extraction and how far those impacts extend into the main peatland area are obvious challenges facing future research. The use of remote-sensing platforms could provide high-resolution data that will be able to differentiate between domestic peat extraction and other types of disturbed peatlands. In particular, the use of unmanned aerial vehicles (i.e. drones), which have been used to map individual peatlands at a very high resolution (e.g. Knoth et al., 2013), offer considerable potential for more detailed mapping of domestic peatlands on the national scale.

\section{Conclusions}

Peatlands managed for extraction are a substantial $\mathrm{CO}_{2}-\mathrm{C}$ emissions hotspot on the landscape scale and further contribute to climate change through significant GHG emissions when the peat is burned or utilised in horticulture. This study, which measured and modelled emissions from a range of sites across the ROI and the UK, has highlighted the importance of generating robust Tier 2 values for different regions and land use categories. Given that the IPCC Tier $1 \mathrm{EF}$ was only based on 20 sites (all from Canada and Fennoscandia), we suggest that data from another 9 sites significantly expands the global data set, as well as adding a new region.

Acknowledgements. Funding to D. Wilson and F. Renou-Wilson by the Environment Protection Agency (Ireland) and by Bord na Móna is acknowledged. Thanks to Ignatius Kelly, Bord na Móna, for rainfall data. Funding to S. D. Dixon and E. Archer (Site IP6) was provided by the Department for Environment, Food and Rural Affairs (UK) under research grant number SP1210. Thanks to Chris Millar, Lancashire Wildlife Trust, and Phil Jepson for access to IP6 and to Cat Moody for fieldwork assistance. Experimental work at IP5 was carried out as part of the RECIPE project, with funding through the European Union Fifth Framework Programme. We would like to thank Christopher MacLellan and Alasdair MacArthur of NERC FSF for their wide-ranging support, including the loan of the FTIR spectrometer and infrared White cell used here. We thank Bruce Main and Bill Luckhurst of King's College London for their technical support with the laboratory burns. Grateful thanks to Eeva-Stiina Tuittila and Anna Laine for useful modelling discussions. We thank the two anonymous reviewers for their insightful comments and suggestions on the earlier draft of the manuscript.

Edited by: A. Neftel 


\section{References}

Akagi, S. K., Yokelson, R. J., Wiedinmyer, C., Alvarado, M. J., Reid, J. S., Karl, T., Crounse, J. D., and Wennberg, P. O.: Emission factors for open and domestic biomass burning for use in atmospheric models, Atmos. Chem. Phys., 11, 4039-4072, doi:10.5194/acp-11-4039-2011, 2011.

Alm, J., Shurpali, N. J., Minkkinen, K., Aro, L., Hytönen, J., Laurila, T., Lohila, A., Maljanen, M., Martikainen, P. J., Mäkiranta, P., Penttilä, T., Saarnio, S., Silvan, N., Tuittila, E.-S., and Laine, $\mathrm{J} .:$ Emission factors and their uncertainty for the exchange of $\mathrm{CO}_{2}, \mathrm{CH}_{4}$ and $\mathrm{N}_{2} \mathrm{O}$ in Finnish managed peatlands, Boreal Environ. Res., 12, 191-209, 2007a.

Alm, J., Shurpali, N. J., Tuittila, E.-S., Laurila, T., Maljanen, M., Saarnio, S., and Minkkinen, K.: Methods for determining emission factors for the use of peat and peatlands - flux measurements and modelling, Boreal Environ. Res., 12, 85-100, $2007 \mathrm{~b}$.

Basiliko, N., Blodau, C., Roehm, C., Bengtson, P., and Moore, T.: Regulation of decomposition and methane dynamics across natural, commercially mined, and restored northern peatlands, Ecosystems, 10, 1148-1165, doi:10.1007/s10021-007-9083-2, 2007

Bertschi, I., Yokelson, R. J., Ward, D. E., Babbitt, R. E., Susott, R. A., Goode, J. G., and Hao, W. M.: Trace gas and particle emissions from fires in large diameter and belowground biomass fuels, J. Geophys. Res.-Atmos., 108, 8472, doi:10.1029/2002jd002100, 2003.

Blodau, C. and Moore, T. R.: Experimental response of peatland carbon dynamics to a water table fluctuation, Aquat. Sci., 65, 47-62, 2003.

Blodau, C., Basiliko, N., and Moore, T.: Carbon turnover in peatland mesocosms exposed to different water table levels, Biogeochemistry, 67, 331-351, 2004.

Bragazza, L., Siffi, C., Iacumin, P., and Gerdol, R.: Mass loss and nutrient release during litter decay in peatland: The role of microbial adaptability to litter chemistry, Soil Biol. Biochem., 39, 257-267, 2007.

Cancellieri, D., Leroy-Cancellieri, V., Leoni, E., Simeoni, A., Kuzin, À. Y., Filkov, À. I., and Rein, G.: Kinetic investigation on the smouldering combustion of boreal peat, Fuel, 93, 479-485, doi:10.1016/j.fuel.2011.09.052, 2012.

Chapman, S., Buttler, A., Francez, A.-J., Laggoun-Défarge, F., Vasander, H., Schloter, M., Combe, J., Grosvernier, P., Harms, H., Epron, D., Gilbert, D., and Mitchell, E.: Exploitation of northern peatlands and biodiversity maintenance: a conflict between economy and ecology, Front. Ecol. Environ., 1, 525-532, 2003.

Chapman, S. J. and Thurlow, M.: Peat respiration at low temperatures, Soil Biol. Biochem., 30, 1013-1021, 1998.

Cleary, J., Roulet, N. T., and Moore, T. R.: Greenhouse gas emissions from Canadian peat extraction, 1990-2000: a life cycle analysis, Ambio, 34, 456-461, 2005.

Couwenberg, J. and Fritze, C.: Towards developing IPCC methane 'emission factors' for peatlands (organic soils), Mires and Peat, $10,1-17,2012$.

Davidson, E. and Janssens, I. A.: Temperature sensitivity of soil carbon decomposition and feedbacks to climate change, Nature, 440, 165-173, 2006.
Department of Environment Food and Rural Affairs: The Natural Choice: securing the value of nature, available at: www. official-documents.gov.uk (last access: 18 May 2015), 2011.

Dise, N. B.: Peatland response to global change, Science, 326, 810 811, 2009.

Drösler, M.: Trace gas exchange and climatic relevance of bog ecosystems, southern Germany, Department für Ökologie, Universität München, Munich, Germany, 182 pp., 2005.

Duffy, P., Hanley, E., Hyde, B., O’Brien, P., Ponzi, J., Cotter, E., and Black, K.: National Inventory Report 2014, Greenhouse gas emissions 1990-2012 reported to the United Nations Framework Convention on Climate Change, Environmental Protection Agency (Ireland), Co. Wexford, Ireland, 469 pp., 2014.

Elsgaard, L., Gorres, C.-M., Hoffmann, C. C., Blicher-Mathiesen, G., Schelde, K., and Petersen, S. O.: Net ecosystem exchange of $\mathrm{CO}_{2}$ and carbon balance for eight temperate organic soils under agricultural management, Agr. Ecosys. Environ., 162, 52-67, 2012.

Evans, C., Renou-Wilson, F., and Strack, M.: The role of waterborne carbon in the greenhouse gas balance of drained and re-wetted peatlands, Aquat. Sci., in press, 2015.

Evans, M., Warburton, J., and Yang, J.: Eroding blanket peat catchments: Global and local implications of upland organic sediment budgets, Geomorphology, 79, 45-57, 2006.

Farrell, C. A. and Doyle, G. J.: Rehabilitation of industrial cutaway Atlantic blanket bog in County Mayo, North-West Ireland, Wetl. Ecol. Manag., 11, 21-35, 2003.

Fenner, N., Freeman, C., and Reynolds, B.: Observations of a seasonally shifting thermal optimum in peatland carbon-cycling processes; implications for the global carbon cycle and soil enzyme methodologies Soil Biol. Biochem., 37, 1814-1821, 2005.

Frandsen, W. H.: Ignition probability of organic soils, Can. J. For. Res., 27, 1471-1477, doi:10.1139/x97-106, 1997.

Frolking, S., Roulet, N. T., Moore, T. R., Lafleur, P. M., Bubier, J. L., and Crill, P. M.: Modeling seasonal to annual carbon balance of Mer Bleue Bog, Ontario, Canada, Global Biogeochem. Cy., 16, 4-1-4-21, doi:10.1029/2001gb001457, 2002.

Gažovič, M., Forbrich, I., Jager, D. F., Kutzbach, L., Wille, C., and Wilmking, M.: Hydrology-driven ecosystem respiration determines the carbon balance of a boreal peatland, Sci. Total Environ., 463-464, 675-682, doi:10.1016/j.scitotenv.2013.06.077, 2013.

Glatzel, S., Kalbitz, K., Dalva, M., and Moore, T.: Dissolved organic matter properties and their relationship to carbon dioxide efflux from restored peat bogs, Geoderma, 113, 397-411, 2003.

Glatzel, S., Basiliko, N., and Moore, T.: Carbon dioxide and methane production potentials of peats from natural, harvested and restored sites, eastern Québec, Canada, Wetlands, 24, 261267, 2004.

Griffith, D. W. T.: Synthetic calibration and quantitative analysis of gas-phase FT-IR spectra, Appl. Spectrosc., 50, 59-70, 1996.

Haddaway, N. R., Burden, A., Evans, C. D., Healey, J. R., Jones, D. L., Dalrymple, S. E., and Pullin, A. S.: Evaluating effects of land management on greenhouse gas fluxes and carbon balances in boreo-temperate lowland peatland systems, Environmental Evidence, 3, 30, doi:10.1186/2047-2382-3-5, 2014.

Howley, M., Dennehy, E., O'Gallachoir, B., and Holland, M.: Energy in Ireland 1990-2011, Sustainable Energy Authority of Ireland, Dublin, 92 pp., 2012. 
IPCC: IPCC Guidelines for National Greenhouse Gas Inventories, Prepared by the National Greenhouse Gas Inventories programme, IGES, Published by the Institute for Global Environmental Strategies (IGES), Hayama, Japan, 2006.

IPCC: Climate Change 2013: The Physical Science Basis. Contribution of Working Group I to the Fifth Assessment Report of the Intergovernmental Panel on Climate Change, Cambridge, United Kingdom and New York, NY, USA, 1535 pp., 2013.

IPCC: 2013 Supplement to the 2006 IPCC Guidelines for National Greenhouse Gas Inventories: Wetlands, edited by: Hiraishi, T., Krug, T., Tanabe, K., Srivastava, N., Baasansuren, J., Fukuda, M., and Troxler, T. G., IPCC, Switzerland, 354 pp., 2014.

Järveoja, J., Laht, J., Maddison, M., Soosaar, K., Ostonen, I., and Mander, Ü.: Mitigation of greenhouse gas emissions from an abandoned Baltic peat extraction area by growing reed canary grass: life-cycle assessment, Reg. Environ. Change, 13, 781-795, doi:10.1007/s10113-012-0355-9, 2012.

Juszczak, R., Humphreys, E., Acosta, M., Michalak-Galczewska, M., Kayzer, D., and Olejnik, J.: Ecosystem respiration in a heterogeneous temperate peatland and its sensitivity to peat temperature and water table depth, Plant Soil, 366, 505-520, doi:10.1007/s11104-012-1441-y, 2013.

Kettridge, N., Turetsky, M. R., Sherwood, J. H., Thompson, D. K., Miller, C. A., Benscoter, B. W., Flannigan, M. D., Wotton, B. M., and Waddington, J. M.: Moderate drop in water table increases peatland vulnerability to post-fire regime shift, Sci. Rep., 5, 1-4, doi:10.1038/srep08063, 2015.

Knoth, C., Klein, B., Prinz, T., and Kleinebecker, T.: Unmanned aerial vehicles as innovative remote sensing platforms for high-resolution infrared imagery to support restoration monitoring in cut-over bogs, Appl. Veg. Sci., 16, 509-517, doi:10.1111/avsc.12024, 2013.

Koehler, A.-K., Sottocornola, M., and Kiely, G.: How strong is the current carbon sequestration of an Atlantic blanket bog?, Glob. Change Biol., 17, 309-319, 2011.

Lafleur, P. M., Moore, T. R., Roulet, N. T., and Frolking, S.: Ecosystem respiration in a cool temperate bog depends on peat temperature but not water table, Ecosystems, 8, 619-629, 2005.

Laine, A., Riutta, T., Juutinen, S., Väliranta, M., and Tuittila, E.-S.: Acknowledging the spatial heterogeneity in modelling/reconstructing carbon dioxide exchange in a northern aapa mire, Ecol. Modell., 220, 2646-2655, 2009.

Lapveteläinen, T., Regina, K., and Perälä, P.: Peat-based emissions in Finland's national greenhouse gas inventory, Boreal Environ. Res., 12, 225-236, 2007.

Leifeld, J., Steffens, M., and Galego-Sala, A.: Sensitivity of peatland carbon loss to organic matter quality, Geophys. Res. Lett., 39, L14704, doi:10.1029/2012GL051856, 2012.

Lindsay, R.: Peatbogs and Carbon - A critical synthesis, University of East London and RSPB Scotland, London, 344 pp., 2010.

Lindsay, R., Birnie, R., and Clough, J.: IUCN UK Committee Peatland Programme Briefing Note No. 10: Peat Bogs, Climate and Climate Change, International Union for the Conservation of Nature, 2014.

Lloyd, J. and Taylor, J. A.: On the temperature dependence of soil respiration, Funct. Ecol., 8, 315-323, 1994.

Lobert, J. M., Scharffe, D. H., Hao, W. M., Kuhlbusch, T. A., Seuwen, R., Warneck, P., and Crutzen, P. J.: Experimental evaluation of biomass burning emissions: Nitrogen and carbon con- taining compounds., in: Global Biomass Burning: Atmospheric, Climatic and Biospheric Implications, edited by: Levine, J. S., MIT Press, Cambridge, Massachusetts, USA, 289-304, 1991.

Mäkiranta, P., Laiho, R., Fritze, H., Hytönen, J., Laine, J., and Minkkinen, K.: Indirect regulation of heterotrophic peat soil respiration by water level via microbial community structure and temperature sensitivity, Soil Biol. Biochem., 41, 695-703, doi:10.1016/j.soilbio.2009.01.004, 2009.

Mander, Ü., Järveoja, J., Maddison, M., Soosaar, K., Aavola, R., Ostonen, I., and Salm, J.-O.: Reed canary grass cultivation mitigates greenhouse gas emissions from abandoned peat extraction areas, GCB Bioenergy, 4, 462-474, doi:10.1111/j.17571707.2011.01138.x, 2012.

McNeil, P. and Waddington, J. M.: Moisture controls on Sphagnum growth and $\mathrm{CO}_{2}$ exchange on a cutover bog, J. Appl. Ecol., 40, 354-367, 2003.

Moore, T. R., Bubier, J. L., Frolking, S. E., Lafleur, P. M., and Roulet, N. T.: Plant biomass and production and $\mathrm{CO}_{2}$ exchange in an ombrotrophic bog, J. Ecol., 90, 25-26, 2002.

Nilsson, M., Sagerfors, J., Buffam, I., Laudon, H., Eriksson, T., Grelle, A., Klemedtsson, L., Weslien, P. E. R., and Lindroth, A.: Contemporary carbon accumulation in a boreal oligotrophic minerogenic mire - a significant sink after accounting for all Cfluxes, Glob. Change Biol., 14, 2317-2332, doi:10.1111/j.13652486.2008.01654.x, 2008.

Ogle, S. M., Conant, R. T., and Paustian, K.: Deriving grassland management factors for a carbon accounting method developed by the Intergovernmental Panel on Climate Change, Environ. Manage., 33, 474-484, 2004.

Paton-Walsh, C., Smith, T. E. L., Young, E. L., Griffith, D. W. T., and Guérette, É.-A.: New emission factors for Australian vegetation fires measured using open-path Fourier transform infrared spectroscopy - Part 1: Methods and Australian temperate forest fires, Atmos. Chem. Phys., 14, 11313-11333, doi:10.5194/acp14-11313-2014, 2014.

Price, J. S. and Schlotzhauer, S. M.: Importance of shrinkage and compression in determining water storage changes in peat: the case of a mined peatland, Hydrol. Process., 13, 2591-2601, 1999.

Regina, K., Nykänen, H., Silvola, J., and Martikainen, P.: Fluxes of nitrous oxide from boreal peatlands as affected by peatland type, water table level and nitrification capacity, Biogeochemistry, 35, 401-418, doi:10.1007/bf02183033, 1996.

Rein, G., Cohen, S., and Simeoni, A.: Carbon emissions from smouldering peat in shallow and strong fronts, Proceedings of the Combustion Institute, 32, 2489-2496, 2009.

Renou-Wilson, F., Barry, C., Müller, C., and Wilson, D.: The impacts of drainage, nutrient status and management practice on the full carbon balance of grasslands on organic soils in a maritime temperate zone, Biogeosciences, 11, 4361-4379, doi:10.5194/bg-11-4361-2014, 2014.

Renou, F., Egan, T., and Wilson, D.: Tomorrow's landscapes: studies in the after-uses of industrial cutaway peatlands in Ireland, Suo, 57, 97-107, 2006

Riutta, T., Laine, J., and Tuittila, E.-S.: Sensitivity of $\mathrm{CO}_{2}$ exchange of fen ecosystem components to water level variation, Ecosystems, 10, 718-733, doi:10.1007/s10021-007-9046-7, 2007.

Roulet, N. T., Lafleur, P. M., Richard, P. J. H., Moore, T., Humphreys, E. R., and Bubier, J.: Contemporary carbon balance and late Holocene carbon accumulation in a northern 
peatland, Glob. Change Biol., 13, 397-411, doi:10.1111/j.13652486.2006.01292.x, 2007.

Saarnio, S., Morero, M., Shurpali, N. J., Tuittila, E.-S., Mäkilä, M., and Alm, J.: Annual $\mathrm{CO}_{2}$ and $\mathrm{CH}_{4}$ fluxes of pristine boreal mires as a background for the lifecycle analyses of peat energy, Boreal Environ. Res., 12, 101-113, 2007.

Salm, J.-O., Maddison, M., Tammik, S., Soosaar, K., Truu, J., and Mander, $\mathrm{U} .:$ Emissions of $\mathrm{CO}_{2}, \mathrm{CH}_{4}$ and $\mathrm{N}_{2} \mathrm{O}$ from undisturbed, drained and mined peatlands in Estonia, Hydrobiologia, 692, 4155, doi:10.1007/s10750-011-0934-7, 2012.

Schouten, M. G. C.: Conservation and restoration of raised bogs: geological, hydrological and ecological studies, Department of the Environment and Local Government/Staatsboshbeheer, Dublin, Ireland, 219 pp., 2002.

Shurpali, N. J., Hyvönen, N., Huttunen, J. T., Biasi, C., Nykanen, H., Pekkarinen, N., and Martikainen, P. J.: Bare soil and reed canary grass ecosystem respiration in peat extraction sites in Eastern Finland, Tellus, 60B, 200-209, 2008.

Silvola, J., Alm, J., Ahlholm, U., Nykänen, H., and Martikainen, P. $\mathrm{J} .: \mathrm{CO}_{2}$ fluxes from peat in boreal mires under varying temperature and moisture conditions, J. Ecol., 84, 219-228, 1996.

Smith, T. E. L., Paton-Walsh, C., Meyer, C. P., Cook, G. D., Maier, S. W., Russell-Smith, J., Wooster, M. J., and Yates, C. P.: New emission factors for Australian vegetation fires measured using open-path Fourier transform infrared spectroscopy - Part 2: Australian tropical savanna fires, Atmos. Chem. Phys., 14, 1133511352, doi:10.5194/acp-14-11335-2014, 2014.

Soini, P., Riutta, T., Yli-Petäys, M., and Vasander, H.: Comparison of vegetation and $\mathrm{CO}_{2}$ dynamics between a restored cut-way peatland and a pristine fen: evaluation of the restoration success, Restor. Ecol., 18, 894-903, 2010.

Stockwell, C. E., Yokelson, R. J., Kreidenweis, S. M., Robinson, A. L., DeMott, P. J., Sullivan, R. C., Reardon, J., Ryan, K. C., Griffith, D. W. T., and Stevens, L.: Trace gas emissions from combustion of peat, crop residue, domestic biofuels, grasses, and other fuels: configuration and Fourier transform infrared (FTIR) component of the fourth Fire Lab at Missoula Experiment (FLAME4), Atmos. Chem. Phys., 14, 9727-9754, doi:10.5194/acp-149727-2014, 2014.

Strack, M. and Price, J. S.: Moisture controls on carbon dioxide dynamics of peat-Sphagnum monoliths, Ecohydrology, 2, 34-41, doi:10.1002/eco.36, 2009

Strack, M. and Zuback, Y. C. A.: Annual carbon balance of a peatland $10 \mathrm{yr}$ following restoration, Biogeosciences, 10, 2885-2896, doi:10.5194/bg-10-2885-2013, 2013.

Strack, M., Waddington, J. A., Bourbonniere, R. A., Buckton, E. L., Shaw, K., Whittington, P., and Price, J. S.: Effect of water table drawdown on peatland dissolved organic carbon export and dynamics, Hydrol. Process., 22, 3373-3385, doi:10.1002/hyp.6931, 2008.

Strack, M., Keith, A. M., and Zu, B.: Growing season carbon dioxide and methane exchange at a restored peatland on the Western Boreal Plain, Ecol. Eng., 64, 231-239, 2014.

Sundh, I., Nilsson, M., Mikkelä, C., Granberg, G., and Svensson, B. H.: Fluxes of methane and carbon dioxide on peat-mining areas in Sweden, Ambio, 29, 499-503, 2000.

Tomlinson, R. W.: Changes in the extent of peat extraction in Northen Ireland 1990-2008 and associated changes in carbon loss, Applied Geography, 30, 294-301, 2010.
Tuittila, E. S. and Komulainen, V. M.: Vegetation and $\mathrm{CO}_{2}$ balance in an abandoned harvested peatland in Aitoneva, southern Finland, Suo, 46, 69-80, 1995.

Tuittila, E.-S., Komulainen, V.-M., Vasander, H., and Laine, J.: Restored cut-away peatland as a sink for atmospheric $\mathrm{CO}_{2}$, Oecologia, 120, 563-574, 1999.

Tuittila, E.-S., Vasander, H., and Laine, J.: Sensitivity of carbon sequestration in reintroduced Sphagnum to water-level variation in a cutaway peatland, Restor. Ecol., 12, 482-492, 2004.

Turetsky, M. R., Kotowska, A., Bubier, J., Dise, N. B., Crill, P., Hornibrook, E. R. C., Minkkinen, K., Moore, T. R., MyersSmith, I. H., Nykänen, H., Olefeldt, D., Rinne, J., Saarnio, S., Shurpali, N., Tuittila, E.-S., Waddington, J. M., White, J. R., Wickland, K. P., and Wilmking, M.: A synthesis of methane emissions from 71 northern, temperate, and subtropical wetlands, Glob. Change Biol., 20, 2183-2197, doi:10.1111/gcb.12580, 2014.

Turetsky, M. R., Benscoter, B., Page, S., Rein, G., van der Werf, G. R., and Watts, A.: Global vulnerability of peatlands to fire and carbon loss, Nat. Geosci., 8, 11-14, doi:10.1038/ngeo2325, 2015.

Verhoeven, J. T. A. and Toth, E.: Decomposition of Carex and Sphagnum litter in fens: Effect of litter quality and inhibition by living tissue homogenates, Soil Biol. Biochem., 27, 271-275, doi:10.1016/0038-0717(94)00183-2, 1995.

Waddington, J. M, and Price, J. S.: Effect of peatland drainage, harvesting and restoration on atmospheric water and carbon exchange, Phys. Geogr., 21, 433-451, 2000.

Waddington, J. M., Warner, K. D., and Kennedy, G. W.: Cutover peatlands: a persistent source of atmospheric $\mathrm{CO}_{2}$, Global Biogeochem. Cy., 16, 21-27, 2002.

Waddington, J. M., Strack, M., and Greenwood, M. J.: Toward restoring the net carbon sink function of degraded peatlands: Short-term response in $\mathrm{CO}_{2}$ exchange to ecosystem-scale restoration, J. Geophys. Res., 115, G01008, doi:10.1029/2009JG001090, 2010.

Webb, N., Broomfield, M., Brown, P., Buys, G., Cardenas, L., Murrells, T., Pang, Y., Passant, N., Thistlewaite, G., and Watterson, J.: UK Greenhouse Gas Inventory, 1990 to 2012. Annual Report for Submission under the Framework Convention on Climate Change, Compiled on Behalf of the UK Department of Energy and Climate Change (DECC) Science Division by Ricardo-AEA, 594, Ricardo-AEA, Oxfordshire, UK, 594 pp., 2014.

Wilson, D., Tuittila, E.-S., Alm, J., Laine, J., Farrell, E. P., and Byrne, K. A.: Carbon dioxide dynamics of a restored maritime peatland, Ecoscience, 14, 71-80, 2007.

Wilson, D., Farrell, C., A., Müller, C., Hepp, S., and Renou-Wilson, F.: Rewetted industrial cutaway peatlands in western Ireland: prime location for climate change mitigation?, Mires and Peat, 11, 1-22, 2013a.

Wilson, D., Müller, C., and Renou-Wilson, F.: Carbon emissions and removals from Irish peatlands: current trends and future mitigation measures, Irish Geography, 46, 1-23, 2013b.

Yokelson, R. J., Griffith, D. W. T., and Ward, D. E.: Openpath Fourier transform infrared studies of large-scale laboratory biomass fires, J. Geophys. Res.-Atmos., 101, 21067-21080, doi:10.1029/96jd01800, 1996. 
Yokelson, R. J., Susott, R., Ward, D. E., Reardon, J., and Griffith, D. W. T.: Emissions from smoldering combustion of biomass measured by open-path Fourier transform infrared spectroscopy, J. Geophys. Res.-Atmos., 102, 18865-18877, doi:10.1029/97jd00852, 1997.
Yokelson, R. J., Susott, R., Ward, D. E., Reardon, J., and Griffith, D. W.: Emissions from smoldering combustion of biomass measured by open-path Fourier transform infrared spectroscopy, J. Geophys. Res.-Atmos., 102, 18865-18877, 2008. 